\title{
Human Rights Work in Papua New Guinea, Fiji and Vanuatu
}

\author{
Aletta Biersack \\ University of Oregon
}

Papua New Guinea (PNG), Fiji and Vanuatu emerged between 1970 and 1980, as they gained independence from their respective colonisers: Australia, Britain and France. As ratifiers of the Convention for the Elimination of All Forms of Discrimination against Women (CEDAW) and the Convention on the Rights of the Child (CRC), they participate in the international human rights regime outlined in the introduction to this volume, the bureaucratic machinery for which lies half way around the world. This UN-anchored network is itself augmented by international non-governmental organisations (INGOs), which pressure ratifying countries and their citizens to conform to the human rights norms they consider universal. Additionally, civil society NGOs devoted to the promotion of women's and girls' rights inform the general public of laws designed to advance women's rights, provide succour and assistance to survivors of gender violence, train citizens in human rights ideology and human rights work, and pressure states to honour their 'due diligence' obligations. Articulating with rights-based international NGOs and partially funded by ex-colonial regional powers, these civil society organisations are indispensable to the advancement of human rights in the western Pacific. 
The three histories offered here trace the strategies and instruments developed by both state and civil society in PNG, Fiji and Vanuatu to curb violence against women and girls. These histories offer insights into the dynamics of the globalising 'ideoscape' (to use Appadurai's term) of human rights, ${ }^{1}$ as human rights ideology streams out from its Euro-American birthplace and heartland ${ }^{2}$ towards peoples and places beholden to alternative principles and values. 'Human rights promote ideas of individual autonomy, equality, choice, and secularism', ideas that do not transfer easily to cultural zones that are 'less individualistic and more focused on communities and responsibilities' ${ }^{3}$ — the western Pacific, for example. Jonathan Xavier Inda and Renato Rosaldo have warned about the inadequacy of the 'hypodermic' model of how globalisation works, ${ }^{4}$ which assumes, implausibly, direct, unmediated 'penetration' by the foreign. 'Cultural materials just do not transfer in a unilinear manner ... They always entail interpretation, translation, and customization on the part of the receiving subject. In short, they can only be understood in the context of their complex reception and appropriation. ${ }^{\prime 5}$ As these three histories attest, human rights doctrine may 'infiltrate' in the form of new, rights-based legislation and policies at the national level and 'grassroots awareness campaigns' at the village level, ${ }^{6}$ but in all three cases reducing gender violence has proved difficult, suggesting that alternative ideologies compete with human rights ideology. Nevertheless, these histories also support Sally Engle Merry's contention that culture is not ossified but contested from within and from without, amenable to change.

1 Arjun Appadurai, 1996, Modernity at Large: Cultural Dimensions of Globalization, Minneapolis: University of Minnesota Press, pp. 33, 35-38.

2 Lynn Hunt, 2007, Inventing Human Rights: A History, New York and London: W.W. Norton \& Company.

3 Sally Engle Merry, 2006, Human Rights and Gender Violence: Translating International Law into Local Justice, Chicago: University of Chicago Press, p. 4.

4 Jonathan Xavier Inda and Renato Rosaldo, 2008, 'Tracking global flows', in The Anthropology of Globalization: A Reader (2nd edition), ed. Jonathan Xavier Inda and Renato Rosaldo, pp. 3-46, Malden, MA and Oxford: Wiley-Blackwell, p. 20.

5 Inda and Rosaldo, 'Tracking global flows', p. 20.

6 See Jean G. Zorn, 'Translating and internalising international human rights law: The courts of Melanesia confront gendered violence', this volume. 
I begin with Papua New Guinea, which celebrated its 40th anniversary of independence recently and which is, for some, the poster child for gender violence in the western Pacific. ${ }^{7}$ I go on to highlight milestones in Fiji's and Vanuatu's struggles to curb gender violence. Despite a turbulent recent political and military history, a history that George shows in her contribution to this volume has negatively impacted on Fijian women, Fiji has developed powerful civil society institutions to combat gender violence and continues to exercise regional leadership in promoting women's rights. All three countries have dual systems of justice: a system of informal justice tied to village or chiefly courts, which emphasises the reconciliation of disputing parties rather than the punishment of offenders, and a formal or state justice system, which enforces national laws by trying and incarcerating offenders in the interest of justice for the victim ${ }^{8}$ and deterrence. In all three countries the duality of the justice system hampers the enforcement of the national laws that are designed to advance the cause of women's and girls' rights. While the tension between these two systems is evident in all three countries, it is not directly addressed here until the third account, which chronicles Vanuatu's efforts to stem gender violence and which is in part guided by Miranda Forsyth's excellent book A Bird that Flies with Two Wings: The Kastom and State Justice Systems in Vanuatu.

\section{Papua New Guinea}

\section{Early statistics}

PNG became independent in 1975, five years later than Fiji and five years before Vanuatu's independence. The PNG Constitution guarantees gender equality. In its 'Basic Rights' section, all citizens, 'whatever their race, tribe, places of origin, political opinion, colour, creed or sex', ${ }^{9}$ are assured '(a) life, liberty, security of person and the

7 Margaret Jolly, 2012, 'Prologue: The place of Papua New Guinea in contours of gender violence', in Engendering Violence in Papua New Guinea, ed. Margaret Jolly, Christine Stewart and Carolyn Brewer, pp. xvii-xxvii, Canberra: ANU E Press.

8 In this writing, I sometimes use the word victim to keep before the reader the suffering of those who have experienced gender violence.

9 GoPNG, Constitution of the Independent State of Papua New Guinea, 1975, 'Basic Rights', p. 5 . 
protection of the law' and '(c) freedom from inhuman treatment'. ${ }^{10}$ PNG also ratified CEDAW, although not immediately, as some considered CEDAW 'not consonant with [PNG's] diverse cultural traditions' ${ }^{11}$ Indeed, realities on the ground contrast sharply with the show of support for women's rights in the PNG Constitution.

The most comprehensive survey of domestic violence to date was conducted by the PNG Law Reform Commission (LRC) between 1982 and 1986. The report's 'Summary and Recommendations' noted that in PNG 'domestic violence is a widespread problem affecting over two-thirds of families in the country ... A certain amount of domestic violence is accepted as normal in most parts of the country, with brideprice seen as justifying a husband's right to beat his wife in many ... societies. Reducing or eliminating the problem therefore means changing attitudes as well as behaviour. ${ }^{12}$ Although the incidence of violence was somewhat lower in urban rather than in rural areas, its severity was greater in major towns, ${ }^{13}$ where, in contrast to village life, it may be speculated husbands had access to alcohol and wives were economically dependent on their husbands and were not able to leave violent husbands. However, 'there is considerable variation across the country, with figures of close to $100 \%$ from some of the Highlands villages surveyed, and half that level' in two coastal provinces: Oro and New Ireland provinces. ${ }^{14}$

\footnotetext{
10 Ibid., pp. 5-6.

11 Martha Macintyre, 2000, “"Hear us, women of Papua New Guinea!": Melanesian women and human rights', in Human Rights and Gender Politics: Asia-Pacific Perspectives, ed. AnneMarie Hilsdon, Martha Macintyre, Vera Mackie and Maila Stivans, pp. 147-71, London and New York: Routledge, p. 149.

12 PNG Law Reform Commission, 1992, Final Report on Domestic Violence. Report No. 14. Boroko, N.C.D., Papua New Guinea.

13 Christine Bradley with Jane Kesno, 2001, Family and Sexual Violence in PNG: An Integrated Long-Term Strategy, Port Moresby: Institute of National Affairs, p. 8.

14 Ibid. See also Richard Eves, 2010, 'Masculinity matters: Men, gender-based violence and the AIDS epidemic in Papua New Guinea', in Civic Insecurity: Law, Order and HIV in Papua New Guinea, ed. Vicki Luker and Sinclair Dinnen, pp. 47-79, Studies in State and Society in the Pacific, no. 6, State, Society and Governance in Melanesia Program, Canberra: ANU E Press, p. 54. On the gender nonviolence of Trobriand Islanders, see Katherine Lepani, 'Proclivity and prevalence: Accounting for the dynamics of sexual violence in the response to HIV in Papua New Guinea', this volume.
} 
Repeatedly mentioned as the cause of high rates of gender violence was the notion that 'a husband has the right to hit his wife as a way to discipline her if she does something to upset him'. ${ }^{15}$ Indeed, gender violence in PNG has enjoyed 'pervasive legitimacy' since at least the 1980 s, ${ }^{16}$ when the LRC study was conducted. PNG is 'a country where violence in general and gender violence in particular is both expected and accepted by women and men alike'.$^{17}$ Christine Bradley, the author of the LRC's Final Report on Domestic Violence, concluded in her 2001 study, Family and Sexual Violence in $P N G$, that, although there was less support for domestic violence in urban than in rural areas, domestic violence was accepted as 'part of normal life', ${ }^{18}$ something she attributed to the 'common attitude that the payment of brideprice entitles a man to control his wife and to discipline her forcefully if he thinks it necessary' ${ }^{19}$

Given the shame associated with sexual violence, sexual violence is underreported, and statistics on it are harder to come by. The most commonly cited data were published in 1994 by the PNG Medical Research Institute ${ }^{20}$ and were based on 423 interviews with men and women and 61 focus groups - in total representing 82 per cent of the population. ${ }^{21}$ Fifty-five per cent of the women questioned said they had been forced into sex. ${ }^{22}$ Male participants indicated that gang rape was a common practice, and 60 per cent of them admitted to having engaged in it. ${ }^{23}$ The findings 'established that women and girls experience a very high level of sexual violence, ranging from unwanted touching

15 Rashida Manjoo, 2013, 'Report of the Special Rapporteur on violence against women, its causes and consequences, on her mission to Papua New Guinea', A/HRC/23/49/Add.2, p. 6, item 19.

16 Margaret Jolly, 2012, 'Introduction - engendering violence in Papua New Guinea: Persons, power and perilous transformations', in Engendering Violence in Papua New Guinea, ed. Margaret Jolly, Christine Stewart and Carolyn Brewer, pp. 1-45, Canberra: ANU E Press, p. 3. See also Laura Zimmer-Tamakoshi, 2001 [1997], “'Wild pigs and dog men": Rape and domestic violence as "women's issues" in Papua New Guinea', in Gender in Cross-Cultural Perspective, ed. Caroline B. Brettell and Carolyn F. Sargent, pp. 565-80, Upper Saddle River, NJ: Prentice-Hall, p. 574.

17 Jolly, 'Introduction - engendering violence in Papua New Guinea', p. 4.

18 Bradley with Kesno, Family and Sexual Violence in $P N G$, p. 10.

19 Ibid.

20 Carol Jenkins (and the National Sex and Reproduction Research Team), 1994, National Study of Sexual and Reproductive Knowledge and Behaviour in Papua New Guinea, Monograph 10, Goroka: Papua New Guinea Institute of Medical Research.

21 Amnesty International, 2009, 'Briefing to the UN Committee on the Elimination of Discrimination Against Women: Violence Against Women', p. 8, n. 5.

22 Ibid., p. 8.

23 Ibid. 
of their bodies and being made to engage in various forms of sexual activity against their will, through to forced sexual intercourse with one or many men at the extreme but still very common end of the spectrum' ${ }^{24}$ Nor is sexual violence restricted to adults. PNG's first report to the committee responsible for reviewing and critiquing reports filed by state party ratifiers of the CRC acknowledged that 'rape, sexual assault and harassment, indecent assault, rape, carnal knowledge, incest and sodomy where children are the victims are common occurrences in contemporary Papua New Guinean society' ${ }^{25}$

\section{The Family and Sexual Violence Action Committee}

Had PNG acted upon the 54 recommendations of the LRC's final report on domestic violence in $1992,{ }^{26}$ domestic violence might have been curbed. Between 1986 and 2000, PNG did take some steps to mitigate gender violence, ${ }^{27}$ but these steps were insufficient to quell domestic violence, which had reached epidemic proportions. Instead of acting upon the LRC's recommendations, 'government focus on domestic violence substantially decreased and the momentum for change dissipated' ${ }^{28}$

The follow-up to the LRC's recommendations would not come until 1999, when Lady Carol Kidu, an expatriate who was married to a prominent PNG citizen and who was the only female Member of Parliament, convened workshops to review the LRC recommendations. Emerging out of these workshops was the Family and Sexual Violence Action Committee (FSVAC), formed 'to bring together government agencies, private sector and civil society partners to develop policy and directly influence government decision making' in the area of family and sexual violence. ${ }^{29}$ The FSVAC promotes legal reform, disseminates knowledge of new laws, provides services to victims, upgrades community prevention and response, collects relevant

\footnotetext{
24 Bradley with Kesno, Family and Sexual Violence in $P N G$, p. 11.

25 Committee on the Rights of the Child, 2003, 'Consideration of reports submitted by States parties under article 44 of the Convention: Initial reports of State parties due in 2000: Papua New Guinea', 21 July. CRC/C/28/Add.20, p. 99, item 396.

26 PNG LRC, 'Summary and Recommendations', in Final Report on Domestic Violence.

27 See Bradley with Kesno, Family and Sexual Violence in PNG, pp. 21-25.

28 Amnesty International, 2006, 'Papua New Guinea - Violence against women: Not inevitable, never acceptable!' p. 27.

29 Consultative Implementation and Monitoring Council (CIMC)/Family and Sexual Violence Action Committee (FSVAC), 2008.
} 
data, develops materials for advocacy and training, and runs national awareness campaigns. Funded by such international donors as the Australian Government, the British High Commission, UNICEF and the UN Population Fund (UNFPA), the FSVAC pursues an 'integrated approach' in seven areas, including law and traditional justice, services for victims, community prevention, and male advocacy for women's rights and the ending of gender violence. ${ }^{30}$ Since its inception in 2000, it has established branch committees in most PNG provinces. ${ }^{31}$ It has also taken the lead in training male advocates for women's rights in its 'focus area': 'Men as Champions and Partners against Violence'. ${ }^{32}$

\section{The Criminal Code (Sexual Offences and Crimes Against Children) Act}

In 2002, the National Parliament passed the Criminal Code (Sexual Offences and Crimes Against Children) Act (henceforth, Criminal Code Act). ${ }^{33}$ The bill was introduced by Lady Carol Kidu, who was at the time the Minister for Community Development, the only governmental bureau attentive to women's and children's issues. In the previous five years, there had been a sharp increase in sexual violence against women. In presenting the bill, Lady Kidu stated that it was 'an important step in re-defining the limits of acceptable behavior' because the bill would shape 'the changing values of our young nation'. ${ }^{34}$

The new law abandoned the archaic term 'carnal knowledge' of older legal language and replaced it with the more graphic term 'sexual penetration'; it defined sexual penetration broadly, to encompass the use of non-penile means of vaginal, anal and oral penetration, including the use of the tongue, fingers and other objects; for the first time it criminalised marital rape; and it acknowledged that females as well as males could be sex offenders. The Criminal Code Act established penalties for sexual penetration without consent that were graduated according to the age of the victim and whether the

\footnotetext{
30 Ibid.

31 Ibid.

32 Ibid.; see also CIMC/FSVAC, 2014, 'Final Stage for male advocacy training-Fiji', Hadibaiatok vol. 1, January-June, p. 5.

33 CIMC/FSVAC, n.d. 'Rape, incest, child abuse: The PNG laws have changed!!!'

34 Carol, Lady Kidu, quoted in John Y. Luluaki, 2003, 'Sexual crimes against and exploitation of children and the law in Papua New Guinea', International Journal of Law Policy and the Family 17(3): 275-307, p. 277.
} 
victim was in 'a relationship of trust with the perpetrator'. ${ }^{35}$ Other provisions criminalised sexual transgressions short of 'penetration': for example, touching a child in a sexual way, forcing a child to touch in a sexual way, exposing oneself to a child in a sexual way, or causing a child to expose himself or herself in a sexual way. Anyone committing these crimes against children would be imprisoned for up to 25 years depending upon the age of the victim, whether the victim and perpetrator was in a relationship of trust, and the number of times the offence was committed. ${ }^{36}$ The new law also modified the evidence laws so that victims of sex crimes no longer had to produce medical evidence or a witness to the act to prove the accusation, making pressing charges less daunting for survivors. ${ }^{37}$

In criminalising sexual offences, the Criminal Code Act aimed to shift cases of rape from the village courts to district and national courts, where the stiff penalties called for in national laws would be imposed upon any defendant found to be guilty. PNG's dual justice system opposes village courts, on the one hand, to district and national courts, on the other. The latter enforce the PNG Constitution and national laws, but village courts function under 'the principles of restorative (rather than punitive) justice', ${ }^{38}$ reconciling disputing parties 'in a manner that restores "peace and harmony"'. ${ }^{39}$ Although village courts were restricted from hearing rape cases, they often did, acting beyond their jurisdiction ${ }^{40}$ by resolving incidents of rape through reconciliation, the offender giving bridewealth or other compensation to his victim's kin to reestablish harmonious relationships. Based on her 2012 visit to PNG, the UN Special Rapporteur on Violence against Women noted in her 2013 report: 'cases of violence against women

35 CEDAW Committee, 2009, ‘Consideration of reports submitted by States parties under article 18 of the Convention on the Elimination of All Forms of Discrimination against Women: Combined initial, second and third periodic report of States parties: Papua New Guinea, CEDAW/C/PNG/3, p. 28, item 2.2.

36 CIMC/FSVAC, 'Rape, incest, child abuse: The PNG Laws have changed!!!'

37 Ibid. See also the summary of The Criminal Code (Sexual Offences and Crimes Against Children) Act in CEDAW Committee, 2009, 'Consideration of reports submitted by States parties under article 18 of the Convention on the Elimination of All Forms of Discrimination against Women: Combined initial, second and third periodic report of State parties: Papua New Guinea', CEDAW/C/PNG/3, pp. 27-29, section 2.2.

38 Department of Justice and Attorney General (DJAG), 2001, 'Village Courts Policy', Port Moresby, p. 3.

39 Ibid.

40 Michael Goddard, 2009, Substantial Justice: An Anthropology of Village Courts in Papua New Guinea, Oxford: Berghahn, pp. 87-88. 
rarely reach the district courts or the National Court. Such cases are mainly being resolved through mediation processes and compensation payments at the village court level' ${ }^{41}$ In this way, national laws are bypassed, and customary justice-with its focus upon healing relationships, especially between men- prevails. $^{42}$

\section{The Lukautim Pikinini Act}

In 2009, the PNG Government passed the Lukautim Pikinini (Child Welfare) Act (LPA), which was informed by the CRC and written and sponsored by Carol Kidu, now Dame Carol and still then the Minister of Community and Development. Children were granted their constitutional rights as well as the right granted in domestic laws and the $\mathrm{CRC}^{43}$ upon whose principles the act was based. The child was defined as anyone under 18 instead of under 16, as in previous legislation. ${ }^{44}$ It gave responsibility for enforcing the law and protecting children from abuse (verbal, physical and sexual) to newly established Child Protection Officers and Community Development Officers, mandating them to provide guidance and counselling to families in support of their parental responsibilities, to investigate allegations that a child is in need of protection and to provide that protection, and to identify, raise awareness, and work with communities to change harmful social, economic and customary practices', among other responsibilities. ${ }^{45}$ It criminalised child abuse, including emotional and psychological harm, imposing a fine of K2,000 (\$US800) and/ or imprisonment for the offence. ${ }^{46}$ Also, it put in place a system of councils and committees: a National Lukautim Pikinini Council to oversee the enforcement of the law; Lukautim Pikinini Councils in every province; and Lukautim Pikinini Committees in every district, to ensure the enforcement of the LPA at all levels. ${ }^{47}$ The intention of the LPA, with its system of councils and committees, was to make

\footnotetext{
41 Manjoo, 'Report of the Special Rapporteur on violence against women', p. 19, item 84.

42 See discussion in Sarah Garap, 1999, 'Struggles of women and girls in Simbu Province', Development Bulletin 50 (October): 47-50, p. 48.

43 GoPNG, 2009, Lukautim Pikinini (Child) Act (LPA), Part II, p. 6, item 5.

44 Ibid., p. 2.

45 Ibid., Part IV, p. 17, item 32.

46 Ibid., pp. 65-66, Part XVI, items 132-33; ibid., Part V, pp. 18-20.

47 'Lukautim Pikinini Act soon to be enforced', 2009, Post-Courier, 29 June. See UNICEF and the GoPNG, 2010, Lukautim Pikinini: Training Manual, Module 10: Child Protection Laws and Policies, 154-63.
} 
community participation in 'ensuring the protection of children under the law ${ }^{\prime 8}$ mandatory and to encourage all citizens to take ownership of this mission. ${ }^{49}$ Importantly, 'Village Courts would have no jurisdiction under the law to hear child abuse [cases] or other matters relating to children' but were expected to refer such matters to a national Lukautim Pikinini Court. ${ }^{50}$

A revised LPA was passed in parliament. It renders marriage of a male and/or female under the age of 18 illegal. ${ }^{51}$ The primary motivation for revising the LPA was an alarming increase in orphans and 'street kids' - homeless children or children who remain in the family but are neglected there and who beg and steal and who are vulnerable to sexual exploitation. ${ }^{52}$ Like the original Act, the revised LPA emphasises children's rights (to protection from abuse and neglect and to equal opportunity and education) but also parental responsibilities and duties. Children who are neglected or abused in their family situation may be removed and placed in the care of the Office for Child and Family Services, which the Department of Community Development will create to implement the revised LPA. ${ }^{53}$ Provincial-level child and family service committees will be formed to assure children's welfare throughout the country. ${ }^{54}$

48 'Lukautim Pikinini Act soon to be enforced'.

49 Ibid.

50 HELP Resources Inc., 2005, 'A situational analysis of child sexual abuse and the commercial sexual exploitation of children in Papua New Guinea', Port Moresby: UNICEF PNG, p. 104; see also LPA, Part V, pp. 18-20.

51 Gorethy Kenneth, 2015, 'Under-age marriage ban', Post-Courier, 13 March, pp. 1-2; Nellie Setepano, 2016, 'PNG marriage laws to be amended as part of reform bundle to legally recognize traditional marriage and protect minors', Pacific Islands Report, 22 August.

52 'PNG defines marriage age', 2015, Radio New Zealand International, 14 March.

53 Ibid. See also Simon Bomai, 2015, 'NEC endorsement of the PNG national Lukautim Pikinini Bill', Ministry of Community Development, Religion and Youth, 24 May.

54 'Lukautim Pikinini Act - passed in Parliament', 2015, Ministry of Community Development, Religion and Youth, 8 June. 


\section{Family Support Centres, Family Sexual Violence Units, and the PNG Family and Sexual Violence Case Management Centre}

Legislation is crucial in the effort to curb gender violence, but institution building is required to help survivors medically, psychologically and legally. This section summarises recent institutional innovations designed to assist survivors of gender violence in PNG.

The PNG National Department of Health and the non-profit Digicel PNG Foundation have both, albeit independently, promoted hospitalbased Family Support Centres (FSCs) to provide short-term shelter, counselling and legal support for victims of gender violence. ${ }^{55}$ Digicel's initiative was undertaken in partnership with the FSVAC and included, along with hospital-based FSCs, women's safe houses (Meri Saif Haus) 'within hospitals and through other service providers' ${ }^{56}$ In a parallel development, Médecins Sans Frontières (MSF) or Doctors Without Borders has developed hospital-based FSCs that combine medical with 'psychosocial' assistance at its three hospital-based support centres (Lae, Tari and Port Moresby). ${ }^{57}$ The PNG Department of Health has committed to establishing such centres in all PNG hospitals. ${ }^{58}$

Whereas FSCs offer survivors of domestic and sexual violence medical and psychosocial assistance, Family and Sexual Violence Units (FSVUs) provide police and prosecutorial support to these same victims, opening up a pathway to the state court system for wouldbe complainants in legal cases involving family and sexual violence. After a pilot phase in 2008, with Australian support, police stations across the country have opened FSVUs, assisting survivors in 'lodging complaints, seeking Interim Protection Orders from the District Court, and linking to safe emergency housing and health services' ${ }^{\prime}{ }^{59}$ The staff of FSVUs are, as the Commissioner of the PNG police force, the Royal

55 Manjoo, 'Report of the Special Rapporteur on violence against women', p. 18, item 77; Digicel PNG, 2010, 'Signing of financial MOU between INA CIMC-FSVAC, UNICEF and Digicel PNG Foundation', 2 February.

56 Digicel PNG, 'Signing of financial MOU'.

57 Médecins Sans Frontières (MSF) (Doctors Without Borders), 2013, 'Papua New Guinea: A comprehensive response to family and sexual violence is crucial', 25 November.

58 Helen Davidson, 2013, 'Papua New Guinea takes first steps to combat "epidemic" of abuse', Guardian Australia, 26 November.

59 Australian High Commission, PNG, 2014, 'Ambassador opens Family and Sexual Violence Unit in Boroko', 8 April. 
Papua New Guinea Constabulary, put it, 'frontline service providers in the law and justice sector ${ }^{60}$ and as such receive training in how to respond sensitively and effectively to the needs of victims of domestic and sexual violence.

It is extremely difficult in cases of family and sexual violence for victims of these crimes to find a way from the rural villages and towns into the courtroom where justice is found. There are many obstacles. However, the police stand at the door of the courtroom and can open it for victims by giving awareness, gaining the trust of the people, responding to people in need of assistance, investigating reported crimes quickly and offering compassionate support to victims of violence. That is the task of the Family and Sexual Violence Unit. ${ }^{61}$

The FSVU operates under the PNG police force, the Royal Papua New Guinea Constabulary (RPNGC). A late December 2015 evaluation of the then existing 15 FSVUs concluded that, even though the FSVU provided a point of entry into the state justice system for complainants, few complaints brought to the FSVU are investigated and even fewer prosecuted because of case overload and a general lack of FSVU resources, the tendency of complainants to withdraw and accept compensation in lieu of adjudication, and the disinterest of the police. ${ }^{62}$

At the beginning of 2014, the Australian Government, which prioritises women's empowerment and the cessation of violence against women and girls in $\mathrm{PNG}^{63}$ announced it would provide AU $\$ 3$ million over three years to fund the PNG Family and Sexual Violence Case Management Centre (CMC) in Lae, the country's second largest city ${ }^{64}$ The award signalled a shift in the Australian Government's PNG aid policy. No longer funding the initiatives of the PNG Government only, the Australian Government would also support PNG civil society initiatives - the development of NGOs such as the CMC, for example. ${ }^{65}$

\footnotetext{
60 Ibid.

61 Voice of ToRot, 2014, 'Madang police fight domestic sexual violence', 1 July.

62 AusAID, 2015, Evaluation of the RPNGC Family and Sexual Violence Units, 31 December.

63 Statement by Julie Bishop, Australia's Foreign Minister, as quoted in Jo Chandler, 2014, 'Violence against women in PNG: How men are getting away with murder', Lowy Institute for International Policy, 29 August.

64 Helen Davidson, 2014, 'Australia pledges \$3m for Papua New Guinea Centre for victims of violence', Guardian Australia, 7 February.

65 Ashlee Betteridge and Kamalini Lokuge, 2014, 'Combatting the family and sexual violence epidemic in Papua New Guinea', Devpolicy blog, Development Policy Centre, 30 June.
} 
The Lae CMC was designed by the ANU Development Policy Centre. ${ }^{66}$ It is run by Femili PNG, a local NGO, ${ }^{67}$ and managed by a committee of Australian and PNG stakeholders, in partnership with The Australian National University (ANU) and Oxfam, the 'implementing partner' ${ }^{6} 8$ CMC targets 'women, men or children who are survivors of intimate partner violence, sexual violence and/or child abuse' ${ }^{69}$

The need for such a case management centre was highlighted in a May 2013 address at ANU given by Ume Wainetti, the national coordinator of the FSVAC. Women who have been treated at FSCs and who have stayed at safe houses have sometimes been brutalised, even murdered, upon returning home, Wainetti said. ${ }^{70}$ The CMC is designed to integrate the medical and counselling support afforded by FSCs with other available services-'police, courts, hospitals, women's refuges, health and domestic and family violence support services' ${ }^{71}$ - and the FSVUs, for example, are to deliver 'a full spectrum of services ${ }^{72}$ to gender violence survivors in the hope of averting such outcomes. Provincial service providers will receive training at the Lae centre 'and take the knowledge back to regional areas with oversight and support from Lae'. ${ }^{73}$ In this way the Lae CMC strives to have a national impact and will serve as a model for CMCs to be built elsewhere in the country in the future.

\footnotetext{
66 'Family and sexual violence', 2014, Ruby.Connection, 24 March; see also Femili PNG, 2014, 'Introducing Femili PNG and the Case Management Centre'.

67 Femili PNG, 'Introducing Femili PNG and the Case Management Centre'.

68 Ibid. See also Betteridge and Lokuge, 'Combatting the family and sexual violence epidemic in Papua New Guinea', p. 10.

69 Ume Wainetti, the National Coordinator of the FSVAC, quoted in Betteridge and Lokuge, 'Combatting the family and sexual violence epidemic in Papua New Guinea', p. 5.

70 Stephen Howes, Kamalini Lokuge, Daisy Plana and Ume Wainetti, 2013, 'Responding to family and sexual violence in PNG: The case for a Case Management Centre', Devpolicy Blog, 11 July.

71 Ibid.

72 Ibid.

73 Davidson, 'Australia pledges \$3m for Papua New Guinea Centre for victims of violence'.
} 


\section{The resurgence of sorcery accusation-related homicides}

Retaliations against alleged sorcerers or witches have grabbed the headlines within PNG and abroad in recent years, and sorcery- and witchcraft-related violence is on the rise. ${ }^{74}$ In most PNG societies, if a person dies unexpectedly and/or is in his or her prime, prominent and/or wealthy, sorcery may be suspected and accusations against alleged sorcerers made. If a death is attributed to these occult forces, either compensation will be demanded of the alleged perpetrator or the accused will be targeted for 'payback' punishment, typically involving torture and/or execution. ${ }^{75}$

Does such activity involve violence against women? In a summary of her 2012 visit to PNG, the UN Special Rapporteur on Violence against Women stated that more women than men are tortured and murdered as a result of sorcery accusations. ${ }^{76}$ Reporting on fieldwork in Goroka, PNG, where sorcery accusations and related homicides are rampant, Richard Eves and Angela Kelly-Hanku indicated that most of the victims of attacks on alleged sorcerers - 30 out of 32 peoplewere females. ${ }^{77}$ It is frequently noted that women who lack male protection - widows and older women with no offspring, women born out of wedlock, and women living at a distance from kin - tend to be vulnerable to sorcery accusations. ${ }^{78}$ Not all researchers agree

74 Following earlier ethnographic work in Africa, some social scientists distinguish witchcraft from sorcery. As Miranda Forsyth and Richard Eves write in their introduction to Talking it Through, published in 2015 by ANU Press, 'Witches are seemingly possessed of an innate and unconscious propensity to harm others, whereas sorcery involves the conscious and deliberate manipulation of objects and/or spells to achieve a desired outcome' (p. 4). However, for present purposes I use the word sorcery to refer to all beliefs and alleged practices pertaining to supernatural homicide. See John P. Taylor and Natalie G. Araújo's contribution to this volume, 'Sorcery talk, gender violence, and the law in Vanuatu', for a Vanuatu example of the spectre of sorcery.

75 Amnesty International, 'Papua New Guinea-violence against women', p. 22; see also Manjoo, 'Report of the Special Rapporteur on Violence against Women', p. 8, item 31.

76 Manjoo, 'Report of the Special Rapporteur on Violence against Women', pp. 8-10. See also Amnesty International, 2011, ‘Papua New Guinea: Violence against women, sorcery-related killings, and forced evictions', Amnesty International submission to the UN Universal Periodic Review.

77 Richard Eves and Angela Kelly-Hanku, 2014, 'Witch-hunts in Papua New Guinea's Eastern Highlands Province: A fieldwork report', in Brief 2014/4, State, Society and Governance in Melanesia, Canberra: The Australian National University.

78 For example, Manjoo, 'Report of the Special Rapporteur on Violence against Women', p. 9, items 34 and 36. See also, Philip Gibbs, 2012, 'Engendered violence and witch-killing in Simbu', in Engendering Violence in Papua New Guinea, ed. Margaret Jolly, Christine Stewart and Carolyn Brewer, pp. 107-35, Canberra: ANU Press. 
that women are more likely than men to be the targets of sorcery accusations. ${ }^{79}$ Practices vary from place to place. However, in general, the perpetrators of revenge killings are overwhelmingly male. It is also telling that the techniques used to torture alleged sorcerers, at least in some places, are sexualised in patently misogynist ways. It seems clear, then, that some, perhaps the majority, of sorcery accusationrelated homicides constitute especially heinous instances of violence against females.

The most notorious recent incident of sorcery accusation-related revenge violence occurred on 6 February 2013, when Kepari Leniata, a 20-year-old mother who was accused of ensorcelling a six-year-old boy, was publicly tortured and burned alive in Mt Hagen, the largest town in the PNG highlands. ${ }^{80}$ In rapid response, the UN Office of the High Commissioner for Human Rights entreated the PNG Government 'to take urgent action to prevent further cases', ${ }^{81}$ as did Amnesty International, which stated that sorcery beliefs were being used as 'a pretext to mask abuse of women' ${ }^{82}$

The public torture and immolation in broad daylight of Kepari Leniata galvanised the PNG Government and citizenry as no other incident had. In the wake of this brutal murder, Women Arise, a coalition of women's groups and NGOs, formed to combat violence against women. At the UN in March 2013, H.E. Robert G. Aisi, the PNG Permanent Representative to the UN, addressed the 57th session of the Commission on the Status of Women on behalf of the PNG

79 Miranda Forsyth, 2013, 'Summary of main themes emerging from the conference on Sorcery and Witchcraft-Related Killings in Melanesia, 5-7 June 2013, ANU, Canberra', Outrigger: Blog of the Pacific Institute, The Australian National University. See also Dan Jorgensen, 2014, 'Preying on those close to home: Witchcraft violence in a PNG village', The Australian Journal of Anthropology 25: 267-86.

80 That alleged sorcerers may be tortured much less killed makes contemporary sorcery a violation of the International Covenant on Civil and Political Rights and the Convention Against Torture, which prohibits both torture and extrajudicial killing. To the extent that females and/ or children are singled out for sorcery accusations and retributions, sorcery-related violence contravenes CEDAW and/or CRC, see Nancy Robinson, then Regional Representative of the UN Office of the High Commissioner for Human Rights, 2013, 'Statement on sorcery-related killings and impunity in Papua New Guinea', Paper presented at the Sorcery and Witchcraft-related Killings in Melanesia: Culture, Law and Human Rights Perspectives Conference, The Australian National University, Canberra, 5-7 June.

81 Peter Kumer, 2013, 'UN urges Papua New Guinea to take action after woman burned alive for witchcraft', United Nations Association of Slovenia, 8 February.

82 Amnesty International, 2013, 'Papua New Guinea must end "sorcery" killings and harassment', 8 February. 
Government, mentioning specifically the murder of Kepari Leniata, a symbol, he said, of 'the savagery' of violence against women and girls in $\mathrm{PNG},{ }^{83}$ as he vowed to eradicate this violence. 'The Government of Papua New Guinea acknowledges that violence against women and girls in the country is a ... human rights concern that must not be tolerated any more. We are therefore committed to combat genderbased violence and also entrench gender equality and empowerment in the country. ${ }^{\prime 4}$

A 'Remembering Kepari Leniata Campaign' erupted on Facebook and, with the help of Women Arise, an overnight haus krai or 'house of mourning' event occurred in Port Moresby, beginning on the night of 14 May and continuing into 15 May 2013, 'to advocate against the unacceptably high rate of violence against women in Papua New Guinea'. ${ }^{85}$ Similar haus krai events occurred elsewhere in PNG, and sympathetic public protests were held in Australia, New Zealand, the US, the UK, Ireland, Japan, the Philippines, Italy and Fiji. ${ }^{86}$ One thousand people came to the Port Moresby haus krai. There, Prime Minister Peter O'Neill apologised to women for the 'despicable violence' against them 'in our communities and throughout the country', ${ }^{87}$ and he pledged tougher laws and penalties and the use of the death penalty to stem gender violence. ${ }^{88}$ Also at the Port Moresby haus krai, the Australian High Commissioner Deborah Stokes, the first female to hold that post, addressed the crowd and pledged solidarity with 'the men and women of Papua New Guinea who are speaking out against violence against women' and with 'those who are taking part in similar Haus Krai events around the globe, to condemn all acts of violence against women' ${ }^{89}$

83 Robert G. Aisi, 2013, 'Statement By H.E. Mr Robert G. Aisi Permanent Representative of Papua New Guinea to the United Nations at the Fifty-Seventh Session of the Commission on the Status of Women', New York, 11 March.

84 Ibid., p. 3, item xii.

85 Nellie Setepano, 2013, 'PNG “Haus Krai" movement gains support abroad', Pacific Islands Report, East-West Center, Honolulu: University of Hawai'i.

86 Ibid.

87 Peter O'Neill, quoted in Eoin Blackwell, 2013, 'PNG says sorry for violence against women', Sydney Morning Herald, 15 May.

88 Heretofore, the death penalty had been reserved for crimes such as treason and piracy.

89 Deborah Stokes, 2013, 'Speech by Australian High Commissioner Ms Deborah Stokes at the "Haus Krai" condemning violence against women, 15 May 2013', Australian High Commission Papua New Guinea, 16 May. 


\section{Recent governmental measures}

Leniata's murder was not an isolated incident. Around the same time there were other attempted and actual tortures and/or murders in retaliation for alleged sorcery homicides in Mt Hagen, the Southern Highlands Province and Bougainville, and there have been sorcery accusation-related revenge murders that have made national and international headlines ever since. ${ }^{90}$ These events partake of a broader pattern of escalation that has been ongoing since the 1980s. In fact, sorcery accusation-related violence in PNG, and especially in the highlands, is 'rapidly becoming one of the world's most urgent human rights issues' ${ }^{\prime 1}$ — so much so that nearby countries have expressed fear that sorcery-related violence will spread into Pacific countries hitherto free of sorcery. ${ }^{92}$

Kepari Leniata's death has served as an important catalyst. The ongoing Remembering Kepari Lenaita Campaign (also referred to as the Haus Krai Movement) has mobilised significant support for clamping down on gender violence. In late May 2013, the PNG Parliament repealed the Sorcery Act, ${ }^{93}$ which recognised allegations of sorcery as a defense in the murder of an alleged sorcerer and which also criminalised sorcery. Also, new provision was made in the Criminal Code Act of 1974 that wilful murder, including sorcery-related executions, would draw the death penalty. ${ }^{94}$ Parliament also replaced the milder penalties for rape imposed by the Criminal Code Act of 2002 with the death penalty for aggravated rape (typically gang rape). ${ }^{95}$

90 For example, Sorcha Pollak, 2013, 'Woman burned alive for witchcraft in Papua New Guinea', Time Magazine, 7 February.

91 Aaron Fernandes, 2014, 'A war on witches', Aljazeera, 1 May.

92 Karen Barlow, 2013, 'Fears sorcery-killings may be spreading from PNG', ABC Radio Australia, 5 June.

93 Matt Siegel, 2013, 'Papua New Guinea acts to repeal sorcery law after strife', New York Times, 29 May.

94 Miranda Forsyth, 2014, 'New draft national action plan to address sorcery accusation-related violence in $\mathrm{PNG}^{\prime}$, in Brief 2014/18, State, Society and Governance in Melanesia, Canberra: The Australian National University.

95 Siegel, 'Papua New Guinea acts to repeal sorcery law after strife'. The international reaction to this repurposing of the death penalty has been mixed at best. Some see in the death penalty the ultimate denial of human rights in that it empowers the state to take a life. Executing rapists or murderers of alleged sorcerers would also have the unintended consequence of perpetuating rather than quelling violence wherever custom requires the eye-for-an-eye justice of retaliation. 
Especially significant, within four months of the Port Moresby Haus Krai and two decades after the bill was first drafted, ${ }^{96}$ parliament passed unanimously the Family Protection Act (FPA), which criminalises domestic violence in an effort to "promote safe, stable and strong families; and to prevent and deter domestic violence at all levels of society'. ${ }^{97}$ Amnesty International attributed the passage of the bill 'to the collective action of grassroots organisations and a multitude of women human rights defenders in $\mathrm{PNG}^{\prime}$ and to the Haus Krai Movement. ${ }^{98}$ The FPA asserts that 'freedom from violence is every person's right ${ }^{\prime 99}$ and defines violence in broad terms, including physical assault and psychological and sexual abuses. A key significance of the FPA is that it criminalises domestic violence, referring cases to district courts in the state justice system, which will award stiff fines and sentences - up to K5,000 (about $\$ \mathrm{US} 2,000$ ) and/or a prison term of up to two years - for acts of domestic violence. ${ }^{100}$ The act explicitly states that payment of bridewealth is not a justification for domestic violence. ${ }^{101}$ Complainants may seek an enforceable physical separation from a family member by applying for a 'Family Protection Order' (FPO) if they feel threatened by that family member. ${ }^{102}$ They may also apply for an 'Interim Protection Order' (IPO), which lasts 30 days and which can be renewed for another 30 days. ${ }^{103}$ Domestic violence survivors do not always report the offence. With the FPA, someone other than the victim - neighbours and kinsfolk, even childrenmay report the offence, triggering police and court penal action and reducing the degree of impunity that domestic offenders tend to enjoy. ${ }^{104}$ Almost 30 years after the initial LRC study, the statistics on domestic violence and rape had not improved. Yet, as Prime Minister $\mathrm{O}^{\prime}$ Neill proclaimed, with the FPA, 'The lid over domestic violence is now removed and the problem exposed as a national issue needing government intervention'. ${ }^{105}$

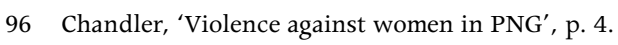

97 GoPNG, 2013, Family Protection Bill, 2013, preamble, 3a and 3b.

98 Amnesty International, 2013, 'Good news: Family protection laws passed in PNG', 26 September.

99 Family Protection Bill, Part I, 4a.

100 Ibid., Part II, 6.1.

101 Ibid., Part II, 6.2.

102 Ibid., Part III, 9.

103 Ibid., Part III, 14.2.

104 Eoin Blackwell, 2013, 'PNG govt backs domestic violence laws', The Australian, News, 2 April.

105 Ibid.
} 
But has the PNG Government, through state actors such as judges, prosecutors, and the police, actually intervened? A September 2015 Human Rights Watch (HRW) report noted that, as of June 2015, when HRW conducted the research on which this report was based: (1) the FPA has not been implemented, ${ }^{106}(2)$ police and prosecutors are 'rarely prepared to pursue investigations or criminal charges against people who commit family violence, even in cases of attempted murder, serious injury, and repeated rape', ${ }^{107}$ (3) victims have difficulty obtaining IPOs $^{108}$ and (4) victims and their children have no shelter or other assistances if they wish to leave their abusers. ${ }^{109}$ These observations are repeated in HRW's November 2015 report, Bashed Up. ${ }^{110}$

\section{Beyond the state: Towards multi-sectoral coalitions and grassroots activism}

The most recent PNG initiative in regard to violence against females is the Sorcery National Action Plan or SNAP. SNAP was developed in June 2014 in a Port Moresby workshop. This was a follow-up to a Goroka, PNG, conference that was held in December 2013, which developed out of an ANU conference in June 2013. A national plan, SNAP nonetheless constitutes a marked departure from state and legislation-centred initiatives in that it relies on a 'holistic', 'comprehensive' approach involving governmental but also nongovernmental actors and entities, including representation of national and international NGOs (for example, the FSVAC and Oxfam), the UN and academic and faith-based organisations and international partners such as the Australian Department of Finance and Trade (which allocates aid money to PNG). ${ }^{111}$ The National Executive Committee approved SNAP in July 2015. ${ }^{112}$ SNAP signals a shift away from a reliance upon government alone towards an investment in

106 Human Rights Watch (HRW), 2015, 'Papua New Guinea: Universal Periodic Review Submission 2015', summary, item 7, 21 September.

107 Ibid., summary, item 8.

108 Ibid., summary, item 9.

109 Ibid., summary, item 10.

110 HRW, 2015, Bashed Up: Family Violence in Papua New Guinea, 4 November. See also MSF, 2016, 'Return to abuser: Gaps in services and a failure to protect survivors of family and sexual violence in Papua New Guinea'.

111 Forsyth, 'New draft national action plan to address sorcery accusation-related violence in Papua New Guinea'.

112 Maria, 2015, 'Papua New Guinea needs its Sorcery National Action Plan as soon as possible!' 24 October. 
hybrid coalitions that integrate public with private and national with international entities in collaborative governance projects. Working with such hybrid coalitions at the community and provincial levels has also been recommended in the effort to thwart violence flowing from sorcery accusations. ${ }^{113}$

Also participating in this hybrid governance project are citizenactivists such as members of the Highland Women Human Rights Defenders Movement (HWHRDM), which 'is an umbrella organisation for different grassroots and community-based organisations working to defend human rights in the seven Highlands provinces'. ${ }^{114}$ The work of these women is 'linked to the broader goals of the international human rights movement', ${ }^{115}$ as they offer counselling and practical assistance to survivors of gender violence, 'monitor and document human rights violations ... hold gender and human rights trainings and workshops ... raise awareness ... and work with the law and justice sectors to improve access to justice for victims' ${ }^{1}{ }^{116}$

HWHRDM signals ever-greater activism among ordinary citizens, especially among women themselves. As Margaret Jolly has observed of PNG today, 'gender violence is increasingly being seen as an important problem by many Papua New Guineans and ... it is possible to mobilise large congregations of women and men in protest ${ }^{\prime} .{ }^{17}$ Tacitly acknowledging this incipient social movement, Amnesty International uses the term 'human rights defenders' more broadly, to signify PNG women's rights supporters who may not identify as human rights defenders but who are nonetheless:

on the frontline of the struggle to stop violence against women [as they] provide temporary shelter for women escaping abusive partners ... offer para-legal advice to women attempting to obtain maintenance orders ... provide counselling, support and advice to victims of genderbased violence ... conduct training on human rights ... who lobby the

113 Philip Gibbs, 2015, 'Confronting sorcery accusation violence in PNG: Will PNG's Sorcery National Action Plan be able to stop the torture and murder of those accused of witchcraft?' Asia and the Pacific Policy Society, Policy Forum, November.

114 Highlands Women Human Rights Defenders Movement website, n.d., 'About us'.

115 Ibid.

116 Ibid., 'Themes'.

117 Jolly, 'Prologue', p. xix. 
police to investigate incidents of sexual violence and violence within the home and who provide medical assistance to the battered, bruised and broken. ${ }^{118}$

PNG, the poster child for gender violence in the western Pacific, may be coming of age.

\section{Fiji}

Bashed Up, Human Rights Watch's most recent exposé of human rights violations in PNG, opens with the alarming statement that 'Family violence in Papua New Guinea is an emergency'. ${ }^{119}$ But 'there are some signs of progress'.${ }^{120}$ Among these are government plans for establishing a national human rights commission, the establishment of a new hotline to help direct survivors toward existing services, and other steps, most of which have already been covered in this discussion. ${ }^{121}$ Nevertheless, the constant refrain of the report is that much more needs to be done. While PNG struggles to operate effectively within the globalised space of human rights work, Fiji continues to exercise regional leadership in this arena. But it, too, strives, with only partial success, to eradicate violence against women and children, as a 2011 survey published at the end of 2013 and discussed below makes clear.

\section{Civil society responses to gender violence}

The Fiji Women's Crisis Centre (FWCC) is renowned throughout the Pacific for its women's rights work. Originally called the Women's Crisis Centre, ${ }^{122}$ it was established in 1984 at a time when the level of sexual violence in Suva was escalating and a new local research centre, the Action Centre for Women in Need, issued 'Rape in Fiji', a report calling for the creation of an entity that could respond to the needs of rape survivors. ${ }^{123}$ That entity would be the FWCC.

118 Amnesty International, 2006, 'Papua New Guinea: Women human rights defenders in action'.

119 HRW, Bashed Up, p. 2.

120 Ibid.

121 Ibid., pp. 2-3.

122 Nicole George, 2012, Situating Women: Gender Politics and Circumstance in Fiji, Canberra: ANU E Press, p. 80.

123 Ibid., pp. 80-81. See also George, "'Lost in translation"”, this volume; and Ruby TaylorNewton, 2009, 'Twenty-five years on, Fiji Women's Crisis Centre stands as a beacon of hope for women', Womensphere, 4 September. 
It soon became evident that female victims suffered additionally from other forms of gender violence, and the scope of FWCC operations expanded to include domestic violence, among other abuses. ${ }^{124}$ Conducting awareness campaigns, distributing pamphlets and posters, and running training sessions on gender violence, the FWCC provoked opposition from conservative groups, including other women's organisations, who 'often argued that the [FWCC's] discussion of domestic violence threatened the integrity of the family $\ldots$ and promoted an agenda that was essentially "anti-men"'. ${ }^{125}$ Some governmental figures also felt that using terms like crisis (not to mention the topic of gender violence itself) tarnished Fiji's reputation as a 'tropical paradise' tourist destination. ${ }^{26}$ Regardless, the FWCC has been from its inception 'the main institution providing psychological, human rights-based crisis counselling and practical support for women and children who have experienced violence in Fiji'. ${ }^{127}$ The Suva-based FWCC has branches in Ba, Nadi and Rakiraki, all on Viti Levu, where Suva is, and Labasa on Vanua Levu, the central island in the Fijian archipelago. ${ }^{128}$ There are plans to open a fifth branch in Savusavu on Vanua Levu. ${ }^{129}$ On the regional level the FWCC is the Secretariat for the Pacific Women's Network on Violence Against Women, a network of human rights organisations devoted to combatting violence against women in the Pacific, which the FWCC was instrumental in establishing and for which it is the coordinating body. ${ }^{130}$ As the Secretariat, the FWCC offers a four-week Regional Training Program (RTP) twice a year for men and women working in the areas of lobbying, counselling, advocacy and community awareness of violence against women and girls in the Pacific. ${ }^{131}$

\footnotetext{
124 Ibid., p. 81.

125 Ibid.

126 Ibid.

127 AusAID, 2009, Stop Violence: Responding to Violence Against Women in Melanesia and East Timor, p. 76.

128 'About us', n.d., Fiji Women's Crisis Centre: Eliminating Violence Against Women in Fiji and the Pacific (FWCC), website.

129 Fiji Women's Crisis Centre, 2013, Somebody's Life, Everybody's Business! National Research on Women's Health and Life Experiences in Fiji (2010/2011): A survey exploring the prevalence, incidence and attitudes to intimate partner violence in Fiji, Suva: FWCC, p. 12.

130 Edwina Kotoisuva, 2007, 'Fiji Women's Crisis Centre: Organising against violence against women', paper presented at Pacific Women, Pacific Plan: Stepping up the Pace to 2010, Secretariat of the Pacific Community, 10th Triennial Conference of Pacific Women, Noumea, New Caledonia, 27-31 May.

131 Fiji Women's Crisis Centre website, n.d., 'Regional training program (RTP)'.
} 
A sister organisation called the Fiji Women's Rights Movement (FWRM) was formed in Suva in 1986. 'Members of the FWCC were ... realising that ... they were facing an uphill battle when it came to the patriarchal structures of national governance. Changing attitudes to women was one thing; dealing with a legal and judicial system that was blind to the realities and experiences of women was another.' ${ }^{132}$ And so, according to Shamima Ali, Coordinator of the FWCC and one of the founders of the FWRM, 'We decided that there was an immediate need for another group, a more academically inclined group, to draft policies and advocate for legislative reform' ${ }^{133}$ This would become a 'feminist human rights organisation that combines local concerns with a global perspective'. ${ }^{134}$ Together with the FWCC, the FWRM would work 'within a rights-based approach to women's issues'. ${ }^{135}$

At first the FWRM addressed sexual violence, conducting an antirape campaign in partnership with an Australian NGO. ${ }^{136}$ In 1987, it organised the first anti-rape march in Fiji, delivering to the parliament a 5,000-signature petition endorsing stiffer sentences for convicted sexual violence offenders. ${ }^{137}$ As the petition suggested, the FWRM's ultimate goal was legal reform. Not surprisingly, the FWRM was an important advocate for the adoption of CEDAW region-wide. ${ }^{138}$ It also lobbied for a progressive Bill of Rights in the 1997 Constitution that protected and promoted women's rights. ${ }^{139}$

In addition to promoting legal reforms, the FWRM provides 'a free legal information and referral service for women in Suva and delivers feminist training to groups and organisations, including developing school and institution-based education and awareness-raising ${ }^{\prime} \cdot{ }^{140}$ In this effort it works in tandem with the Suva-based Regional Rights and Resources Team (RRRT), which provides 'training, advocacy and

132 Fiji Women's Rights Movement (FWRM), 2012, 'Herstory: Celebrating 25 Years of Balancing the Scales, 1986-2011', Suva: FWRM.

133 Quoted in FWRM, 'Herstory', p. 2.

134 Ibid., p. 1.

135 Ibid., p. 2.

136 George, Situating Women, p. 109.

137 Ibid., p. 119.

138 Ibid.

139 FWRM, 'Herstory', p. 30.

140 AusAID, 2008, Violence Against Women in Melanesia and East Timor: Building on Global and Regional Promising Approaches, Report prepared by the Office of Development Effectiveness, p. 155. 
resourcing on human rights issues relating to violence against women to the police, the judiciary and community-based organisations' for the entire Pacific. ${ }^{141}$ The RRRT and the FWRM train police officers, magistrates, judges and prosecutors on violence against women. ${ }^{142}$ The FWCC, the FWRM and the RRRT were 'the first in Melanesia to tackle violence against women from a human-rights perspective' ${ }^{143}$ as well as the first 'to create broad community acceptance that violence should be viewed through a human rights framework'. ${ }^{144}$

\section{State responses to gender violence}

Together with the National Council of Women Fiji, the FWCC and the FWRM lobbied successfully for the bureaucratisation of the government's response to women's concerns. In 1987, just three years after the FWCC was formed and one year after the FWRM came into existence, the Department for Women and Culture was created. ${ }^{145}$ This would become the Ministry for Women, Children and Poverty Alleviation (henceforth, Ministry for Women). ${ }^{146}$ The Ministry for Women combines the Department of Women, which advises the Fijian Government on public policy bearing on issues of women and gender, and the Department of Social Welfare, which is responsible for children's welfare.

In 1998, the Ministry for Women spearheaded the effort to put in place a National Women's Plan of Action (WPA), which was in effect from 1999 to 2008. The WPA designated the elimination of violence against women and children as one of five areas of concern. It acknowledged that there was an 'ingrained bias against women' ${ }^{147}$ and that Fiji had been slow to recognise violence against women as a problem because it was 'identified as a family matter that should remain in the private domain, in the belief that intervention would have an adverse effect

141 AusAID, Stop Violence, p. 80.

142 AusAID, Violence Against Women in Melanesia and East Timor, p. 155; AusAID, Stop Violence, p. 74.

143 AusAID, Violence Against Women in Melanesia and East Timor, p. 152.

144 Ibid.

145 Ministry for Social Welfare, Women and Poverty Elimination, 2014, 'Fiji's national report on the 20-year review of the implementation of the Beijing Platform for Action', p. 3.

146 This ministry has operated under a number of appellations: Ministry for Social Welfare, Women and Poverty Elimination and Ministry for Women and Culture, for example.

147 Ministry for Women and Culture, 1998, 'The Women's Plan of Action 1999-2008', vol. 2, section on violence against women and children, 'Executive summary'. 
on the family unit'. ${ }^{48}$ In addition, violence against women in the family was said to be 'entrenched' and either tolerated as disciplinary or ignored. ${ }^{149}$ Yet the plan did not argue that present day violence against women reflected the practices of the past. The importance of family relationships has indeed been longstanding, but 'the dynamics that determine family relationships have changed', ${ }^{150}$ resulting in myriad problems, including poverty, drug abuse, crime and violence against women and children. ${ }^{151}$ A revised WPA came into effect in 2009, effective through 2018. Also, a National Gender Policy was put in place in 2014 to promote gender equality and sustainable development, which was thought to depend on achieving gender equality ${ }^{152}$ In 2009, the Ministry for Women would launch the first Zero Tolerance Violence Free Community (ZTVFC) at Koroipita, ${ }^{153}$ a community outside the Viti Levu city of Lautoka, the second largest urban centre in Fiji. As will be discussed, the ZTVFC initiative has assumed tremendous importance in Fiji's war against gender violence.

The Fijian Police Force has taken important steps towards aiding victims of domestic and sexual violence. Beginning in 1995, it has opened up Sexual Offences Units (SOUs). Like PNG's FSVUs, Fiji's SOUs are designed to give direct assistance to the victims of domestic violence and sexual assault and also to direct them towards the state justice system, bypassing the village courts of the informal justice system. ${ }^{154}$ Each SOU takes statements from survivors, transports them to medical facilities, and refers them to other agencies (the FWCC, for example) for counselling and other support. ${ }^{155}$ They do so under a 'no drop' policy that requires police to record and pursue a charge of domestic violence once it is filed, even if the accuser changes (usually) her mind and wants to withdraw the charge. ${ }^{156}$ Before the 'no drop' policy was instituted, 'women who reported domestic abuse cases to the police often faced severe pressure from family, in-laws and

\footnotetext{
148 Ibid., vol. 2, section on violence against women and children, 'Overview'.

149 Ibid.

150 Ibid.

151 Ibid.

152 Fijian Government, 2014, 'Fiji's national gender policy approved', 25 February.

153 Fijian Government, 2013, 'Violence free campaigns paying dividends for communities', press release, 6 July.

154 AusAID, Violence Against Women in Melanesia and East Timor, p. 152.

155 AusAID, Stop Violence, p. 74. However, Fiji's SOUs appear to suffer from inadequate resources and demanding workloads.

156 AusAID, Violence Against Women in Melanesia and East Timor, p. 156.
} 
community members, and often returned to the police station shortly afterward to withdraw their complaints'. ${ }^{157}$ In fact, 'the police and courts ["overwhelmingly male"] ${ }^{158}$ have been reluctant to prosecute violence against women and impose penalties ... Both police and courts find ... cases [of domestic violence] embarrassing and often do not support women who complain.' ${ }^{159}$

Fiji's Family Law Act (FLA) was passed in 2003. ${ }^{160}$ The passage of the Act was 'the culmination of a 15-year process that had frequently been stalled by Fiji's coups'. ${ }^{161}$ The law aimed to provide 'a level playing field for women and men' in regard to divorce, maintenance and custody of children. ${ }^{162}$ Divorcées were afforded 'enforced spousal maintenance should they be raising children as single parents', ${ }^{163}$ thus helping women 'escape violent domestic relationships through no-fault divorce provisions'. Courts could also issue restraining orders against a violent partner, and the police were granted powers to enforce such orders. ${ }^{164}$ Those exercising jurisdiction under the terms of the FLA were instructed to 'have regard to' the two treaties discussed here, CRC and CEDAW. ${ }^{165}$ While women's rights advocates hailed the new law, opponents derided its corrosive effects on the grounds that it made obtaining a divorce easier, thus undermining indigenous conceptions of leadership, property rights and inheritance and threatened the religious sanctity of marriage'. ${ }^{166}$

The intention of the police's 'no drop' policy, like the work of the police's SOUs, was to direct cases of domestic violence towards the state justice system. Consistent with that goal, the Domestic Violence Decree (DVD) of 2009 prohibited the use of reconciliation practices (principal of which was the bulubulu process described in Newland's contribution to this volume) to resolve instances of domestic violence. Henceforth instances of domestic violence would require prosecution and sentencing in the state courts, although evidence of the perpetrator

157 Ibid.

158 Merry, Human Rights and Gender Violence, p. 144.

159 Ibid.

160 Republic of Fiji Islands, 2003, Family Law Act.

161 George, "Lost in translation"', this volume.

162 Fiji Women's Rights Movement, n.d., 'Fiji: Family Law Bill passed'.

163 George, "'Lost in translation"', this volume.

164 Republic of Fiji Islands, 2003, Family Law Act, items 202(1) and 203.

165 Ibid., item 26(e).

166 George, Situating Women, p. 181. 
and victim having been reconciled could be used as a mitigating factor in determining the offender's sentence. ${ }^{167}$ The DVD also enabled family members, co-residents, neighbours, police and welfare officers, and any entity - rights-based NGOs, for example - to apply for a protection order on behalf of the victim to protect (typically her) from further harm. ${ }^{168}$

Also in 2009, the Fiji Parliament passed the Crimes Decree (CD). The CD replaced the earlier definition of rape as the 'forced penile penetration of the female organ' with a definition of rape as nonconsensual 'sexual penetration', broadly defined, as penetration of genitalia, anus or mouth by means of a finger or other object. ${ }^{169}$ Cases that were tried as 'indecent assault' ${ }^{\prime 170}$ would now be tried as rape, drawing the stiffer penalty of 25 years ${ }^{171}$ to life. ${ }^{172} \mathrm{~A}$ child younger than 13 years of age was deemed incapable of giving consent. ${ }^{173}$ In addition, a home or property owner who suspects that a person under 13 or a girl under 16 has been defiled on his (typically) property and who fails to report the crime, would be charged. ${ }^{174}$

\section{How effective?}

Fiji ratified CRC in 1993 and CEDAW in 1995, albeit with two reservations. The more important of these concerned CEDAW's article $5 a$, which requires states to 'modify the social and cultural patterns of conduct of men and women' to promote gender equality. Fiji objected to this article 'on the grounds that it "impinges on our cultural values and social norms of behavior that are the mainstay of traditional societies like Fiji"'. ${ }^{175}$ However, the Constitutional Amendment Act of 1997 granted equal rights to female and male citizens alike, ${ }^{176}$ and Fiji

167 Nazhat Shameem, 2012, 'The Domestic Violence Decree 2009, Fiji', pp. 10-11.

168 Ibid., p. 4.

169 Republic of Fiji, 2009, 'Crimes Decree 2009', in Republic of Fiji Islands Government Gazette 10(95) (5 November), p. 1061, item 88.5.

170 'New crime decree in Fiji to assist fight against sexual abuse', 2010, Solomon Times Online, 25 January.

171 Republic of Fiji, 'Crimes Decree 2009', p. 1063, item 93(1).

172 Ibid., p. 1097, item 207(1).

173 Ibid., p. 1097, item 207(3).

174 'New crime decree in Fiji to assist fight against sexual abuse'.

175 CEDAW Committee, 2000, 'Initial report of States parties: Fiji Islands', CEDAW/C/FJI/1, p. 4.

176 CEDAW Committee, 2008, 'Consideration of reports submitted by States parties under article 18 of the Convention on the Elimination of All Forms of Discrimination against Women. Combined second, third and fourth periodic reports of States parties: Fiji', CEDAW/C/FJI/2-4, p. 8. 
withdrew its CEDAW reservations in 2000, filing its first report with the committee that reviews and critiques state party reports that same year.

Fiji's combined second, third and fourth report would follow eight years later. It made it abundantly clear that, despite Fiji's civil society organisations, laws and state institutions, gender violence remained a serious problem. Given the 'patriarchal' nature of Fijian society, ${ }^{177}$ 'gender inequality infiltrates all aspects of life including the tacit acceptance of violence against women in the home' ${ }^{178}$ A 2008 report from the UNFPA concurred, noting that violence is used by men to keep "wwomen in their place", especially if women show signs of going beyond the traditional gender roles accorded them by society. Ideas and attitudes on traditional gender roles are so engrained in Fiji that cases of sexual harassment and abuse are often not thought of as criminal offenses' ${ }^{\prime}{ }^{179}$ Of the women the UNFPA surveyed, 66 per cent were the victims of domestic violence, 30 per cent were repeatedly abused, and 74 per cent of female victims neither sought medical attention nor reported the incident to the police. ${ }^{180}$ Women who reported violent husbands to the police were seen to be 'disrespectful of their marriage vows ... or seen to be challenging cultural norms that strive to keep the family together, despite adverse and dangerous situations' ${ }^{\prime}{ }^{181}$ A similar kind of pressure was placed on incest victims. 'When the victim chooses to pursue the case through the justice system [instead of informal mediation], family members sometimes step in to defend the reputation of the offender, and put pressure on the victims not to "tarnish the family name" or "break up the family"'. ${ }^{182}$ Indeed, "There is a lot of pressure on women to reconcile with their husbands/partners following incidents of domestic violence, rather than seek access to justice. This pressure can come from traditional, community and religious leaders, the Police, the Family Court and other Courts. ${ }^{\prime 183}$ In regard to the police's 'no drop' policy, this may have 'improved police response to violence against women overall',

177 Ibid., p. 48, item 128.

178 Ibid., p. 48, item 127.

179 UN Population Fund (UNFPA), 2008, 'An assessment of the state of violence against women in Fiji', Suva: UNFPA Pacific Sub Regional Office, p. 19.

180 Ibid., p. 13.

181 Ibid.

182 Ibid., p. 19.

183 FWCC, Somebody's Life, Everybody's Business!, p. 17. 
but police insensitivity to domestic violence and its impacts remain. ${ }^{184}$ In fact, the 'no drop' policy has had the unintended consequence of discouraging women from coming forward lest their assailant be sentenced and incarcerated. ${ }^{185}$ All in all, reporting to the police had become 'a last resort'. ${ }^{186}$

Whether because of police indifference, women's fear of reprisals or both, the same fate awaited the Domestic Violence Decree (DVD) of 2009. According to Madam Nazhat Shameem - the first woman to be appointed judge of the High Court of Fiji ${ }^{187}$ and who is presently Fiji's first Permanent Representative to the UN Office in Geneva, where she now resides ${ }^{188}$ - 'most cases of domestic violence ... never come to the attention of the media, or the High Court. Sadly most cases of rape and incest within a family do not lead to ... a domestic violence sentence. This is so, even in the High Court.' ${ }^{189}$ As a result, the purpose of the DVD, 'which was to promote gender equality in the courts, and to promote gender competence within the judiciary, is defeated'. ${ }^{190}$ The predominant mechanism for resolving domestic conflict remains reconciliation, which the Penal Code allows but does not favour. ${ }^{191}$ Women who succumb to the 'pressure ... to reconcile with their husbands/partners following incidents of domestic violence, rather than seek access to justice ${ }^{192}$ expose themselves to '[r]e-victimisation' ${ }^{193}$ Despite progressive legislation, the previous status quo largely prevails.

\footnotetext{
184 AusAID, Violence Against Women in Melanesia and East Timor, p. 154.

185 Ibid., p. 156.

186 Ibid.

187 Australian Centre for Leadership for Women, 2012, 'Nazhat Shameem', 1 June.

188 Fijian Government, 2014, 'Nazhat Shameem to be Fiji's Permanent Representative to the UN Office in Geneva', 8 May.

189 Shameem, 'The Domestic Violence Decree 2009', p. 12.

190 Ibid.

191 AusAID, Violence Against Women in Melanesia and East Timor, p. 158.

192 FWCC, Somebody's Life, Everybody's Business!, p. 17.

193 Ibid.
} 


\section{Community-based advocacy}

In 2002, the FWCC began a Male Advocacy Program in partnership with the Ministry of Women. ${ }^{194}$ The program is based in a human rights framework and, much like the program Philip Gibbs describes in his contribution to this volume, helps men recognise their complicity in patterns of behaviour that undermine women's rights and reform their behaviour. Male advocates advocate for women's rights and serve as role models to other men and boys. Many participants in the Male Advocacy Program experience behavioural and attitudinal changes. ${ }^{195}$

As already indicated, the Ministry for Women piloted one of its most important programs in 2008. The Zero Tolerance Violence Free Communities (ZTVFC) Campaign emphasises changing attitudes and behaviours through human rights education and awareness programs ${ }^{196}$ within indigenous (iTaukei) communities for the purpose of promoting women's rights and eliminating violence against women and children. The aim is to 'empower women, men and children through human rights education using media campaigns and community training'. ${ }^{197}$ Participation in the program is entirely voluntary. After a successful pilot, the ZTVFC began in earnest. As of July 2014, 87 communities were participating in the program, with another 29 readying for awareness trainings. ${ }^{198}$ The number of communities participating or wanting to participate continues to rise. A 'gatekeeper committee' comprised of village leaders, including women and youth, is chosen by the village to monitor violence against women and children in the village. The committee serves as the 'eyes and ears' of the local campaign as it operates in particular locations. ${ }^{199}$ Committee members are trained in human rights and how to respond to cases of abuse in their village. Once the community becomes free of violence, a billboard is erected in front of the village announcing its violence-

194 AusAID, Violence Against Women in Melanesia and East Timor, p. 161; Felix Chaudary, 2015, 'Call for commitment', Fiji Times Online, 23 March.

195 Seeds Theatre Group Inc., 2015, 'Male advocacy for human rights'.

196 AusAID, Stop Violence, pp. 80-81.

197 Ibid., p. 80.

198 Elizabeth Rokosuka, 2014, 'Zero tolerance violence free communities to report on crimes', Fijivillage.com, 6 July.

199 Fijian Government, 2013, 'Violence free campaigns paying dividends for communities', press release, 6 July. 
free status. ${ }^{200}$ Mobilising the public as gender violence watchdogs, the ZTVFC campaign empowers survivors by offering them human rights-informed communal support and in the process renders gender violence no longer a private but, instead, a most public matter.

How to explain the popularity of the ZTVFC, which has seen community after community queuing up to participate? Perhaps this way: gatekeeper committees are able to reconcile those whose relationships are marred by sexual abuse and domestic violence before particular incidents are reported to the police for prosecution, in effect rehabilitating reconciliation practices. This is despite the fact that the DVD, which village-based actors find 'a bit too harsh particularly when couples are able to reconcile almost immediately after an abuse experience', ${ }^{201}$ requires prosecution of domestic violence in the state justice system. Staffed predominantly by male leaders, gatekeeper committees 'mediate between the community and the police department', ${ }^{202}$ possibly bridging the difference between traditional or neo-traditional practices, on the one hand, and rights-informed legal practices, on the other. Operating under governmental agencies devoted to women's rights, participants in these 'zero tolerance' communities are in effect recruited to the global human rights movement, albeit as community-based activists.

\section{At the dawn of the 'post-2015' era}

The brutal execution of Kepari Leniata in February 2013 galvanised PNG to clamp down on sorcery accusation-related gender violence. More than two years later, in April 2015, another brutal murder focused attention on the persistence of violence against women in Fijian society. Losana McGowan, a Fijian journalist and women's rights advocate, was bludgeoned to death by her partner. Those associated with the cause of women's rights argued that the death, otherwise pointless, could "reinvigorate", focus and discussion on women's abuse in Fiji'. ${ }^{203}$ The FWRM saluted Losana for her 'exuberant personality and zest

200 A photograph of such a billboard appears in Rokosuka, 'Zero tolerance violence free communities to report on crimes'.

201 Geraldine Coutts, 2012, 'Fiji women's minister defends domestic violence decree', ABC Radio Australia, 6 December.

202 Ibid.

203 Alistar Kata, 2015, 'Death of Losana McGowan opens door for wider talks on domestic abuse', Fiji Sun Online, 19 April. 
for life' and pledged to 'recommit to fighting gender-based violence in all its forms'. ${ }^{204}$ But it was the response of Fiji's Prime Minister, the Honourable Voreqe (Frank) Bainimarama, that mattered the most. 'For too long, Fijian society in common with other Pacific societies has turned a blind eye to what goes on in the privacy of people's homes. Worse, we've tolerated, even encouraged, a culture in which spouses or partners are entitled to use violence to resolve disputes or bring supposedly errant family members into line', ${ }^{205}$ he said. He went on to issue a clarion call for the Fijian public to tackle domestic violence. Indeed, the time for action 'to bring this scourge to an end is long overdue', $^{206}$ he said. Within months, the Minister for Women would deride Fiji's violence against women as a 'national shame'.$^{207}$

The event occurred about 18 or 19 months after the FWCC had released the findings of its national survey of violence against women and girls, which was conducted with the cooperation of the Fiji Islands Bureau of Statistics and paid for with Australian aid money, in the form of a 300+-page report called Somebody's Life, Everybody's Business! The survey was based on interviews conducted in 3,538 households, including 3,193 interviews with individual women. ${ }^{208}$ It found that 64 per cent of the Fijian women surveyed who had at some time been in an intimate relationship ('ever-partnered women', as the report called them) had experienced sexual and/or physical violence by a husband or intimate partner, ${ }^{209}$ a rate that is twice the global prevalence for physical and/or sexual abuse for ever-partnered women. ${ }^{210}$ Moreover, 29 per cent of women were forced to have their first sexual experience. ${ }^{211}$ Overall, 71 per cent of women had experienced physical and/or sexual violence at the hands of someone (partner or not) at some point in their life. ${ }^{212}$ In fact, every day ' 43 women are injured, 1 is permanently

\footnotetext{
204 'FWRM pays tribute to former journalist and women human rights defender', 2015, The Jet, 9 April.

205 Reginald Chandar, 2015, 'Fiji Government has "zero tolerance" for domestic violence: PM', Pacific Island Reports, 29 April.

206 Ibid.

207 Niklas Pedersen, 2015, 'Fiji women's minister calls gender violence a "national shame"', Pacific Island Reports, 10 September.

208 FWCC, 2013, Somebody's Life, Everybody's Business!, p. 2.

209 Ibid.

210 Ibid., p. 3.

211 Ibid.

212 Ibid.
} 
disabled, and 71 lose consciousness' ${ }^{213}$ The report noted that physical and/or sexual violence among iTaukei or Indigenous Fijians, the ethnic group treated in Newland's contribution to this volume, was almost twice as much as the physical and/or sexual violence among Indo-Fijian women. ${ }^{214}$

The senseless murder of Losana McGowan put an exclamation point on the survey's findings. Fiji could not rest on its laurels as the premier advocate for women's and children's rights in the western Pacific; there was more work to be done. In September 2015, the Ministry for Women announced that it was working towards strengthening its partnership with the police to enhance women's access to the state justice system. ${ }^{215}$ This and other recent initiatives have been undertaken in the context of the Interagency Taskforce on Elimination of Violence Against Women (hereafter, EVAW taskforce), which was convened to support the two iterations of the Women's Plan of Action under the leadership of the Minister for Women. The EVAW taskforce pursues 'holistic' means to develop 'new strategies to eliminate violence against women and children' ${ }^{216}$ The EVAW taskforce convenes agents from government, civil society, faith-based organisations, multilateral organisations and the Australian Department of Foreign Affairs and Trade, a principal sponsor of women's rights initiatives in the western Pacific. ${ }^{217}$ 'The taskforce is working collaboratively to have the best practice responses by police and other service providers when working with Domestic Violence Decree, Child Welfare Decree and other legislation that addresses crimes of violence and sexual violence against women and children. There is political will and a sense of urgency to protect the rights of women and children in Fiji.. ${ }^{218}$ The first order of business for the EVAW taskforce would be to review the Zero Tolerance Violence Free Communities program. ${ }^{219}$ In these and other ways, Fiji continues to exert regional leadership, developing human rights concepts, practices and institutions that neighbouring countries may well emulate.

\footnotetext{
213 Ibid., p. 4.

214 Ibid., p. 42, Figure 4.10.

215 Talebula Kate, 2015, 'Rethink on strategies to curb violence against women', Fiji Times Online, 14 September.

216 Ibid.

217 Ibid.

218 Fijian Government, 2015, 'EVAW taskforce to meet next week', 4 September.

219 Ibid.
} 


\section{Vanuatu}

In Vanuatu, a sprawling Y-shaped archipelago lying southeast of the Solomon Islands, 'political and social life including gender roles and power relations between male and female are greatly influenced by traditional cultural attitudes and practices - kastom', ${ }^{220}$ the Bislama word many translate as custom or culture even though it is 'not simply customary $^{\prime 221}$ but a historical product that evokes 'not so much the totality of ancestral practices as a particular selection of such practices for the present' ${ }^{222}$ Some see kastom as superior to Western ways and resist change. But given 'the widespread open-mindedness of the chiefs and their willingness to embrace new ideas', ${ }^{223}$ kastom is also open to change. This tension between resistance and openness to change governs the unfolding history of women's rights in Vanuatu. It is manifested most immediately in Vanuatu's two justice systems, discussed in the next section. This sets the stage for an examination of governmental and civil society efforts to realise constitutional guarantees of human rights and gender equality and the sometime opposition to these values. The final segment uses the 2011 survey conducted by the Vanuatu Women's Centre (VWC) to gauge the efficacy of these efforts. Just as the FWCC's Somebody's Life, Everybody's Business! provided a reality check for Fiji's women's rights advocates, the VWC's Vanuatu National Survey on Women's Lives and Family Relationships tells a dark story of progressive initiatives thwarted and of unmet rights-based goals.

220 Peggy Fairbairn-Dunlop, 2009, Pacific Prevention of Domestic Violence Programme: Vanuatu Report, prepared for the New Zealand Government, Wellington: Victoria University of Wellington, p. 18.

221 Lamont Lindstrom, 1997, 'Chiefs in Vanuatu today', in Chiefs Today: Traditional Pacific Leadership and the Postcolonial State, ed. Geoffrey M. White and Lamont Lindstrom, pp. 211-28, Stanford: Stanford University Press, p. 212.

222 Margaret Jolly, 1997, 'Woman-nation-state in Vanuatu: Women as signs and subjects in the discourses of kastom, modernity and Christianity', in Narratives of Nation in the South Pacific, ed. Ton Otto and Nicholas Thomas, pp. 133-62, Amsterdam: Harwood Academic Publishers, p. 139. See also discussion in Forsyth, A Bird that Flies with Two Wings, Chapter 3.

223 Forsyth, A Bird that Flies with Two Wings, p. 111. 


\section{The bird that flies with two wings}

Vanuatu's Constitution proclaims all citizens to be 'entitled to ... fundamental rights and freedoms of the individual without discrimination on the grounds of race, place of origin, religious or traditional beliefs, political opinions, language or $\operatorname{sex}^{\prime},{ }^{224}$ and that among these 'fundamental rights and freedoms of the individual' are life, liberty, security of person, and protection of, and equal treatment from, the law. ${ }^{225}$ Here, as in the constitutions of Papua New Guinea and Fiji, there is a strong flavour of 18th-century American and French revolutionary ideals.

But the Vanuatu Constitution also valorises kastom. 'Customary law shall continue to have effect as part of the law of the Republic of Vanuatu. ${ }^{226}$ If no 'rule of law' is applicable, then the court will decide the matter 'wherever possible in conformity with custom'; ${ }^{227}$ children are to be reared in such a way that they understand custom; ${ }^{228}$ village and island courts will have 'jurisdiction over customary ... matters and shall provide for the role of chiefs in such courts' ${ }^{229}$ To bolster kastom ideology and practice, the Vanuatu Constitution created the National Council of Chiefs (NCC) or Malvatumauri, a body composed of 'custom chiefs' elected by their peers and representing the various ethnic and linguistic groups of Vanuatu. The identity 'custom chief' (kastom jif), like kastom itself, is not 'simply customary' ${ }^{230}$ but has been 'shaped by the events and interests of postcontact, colonial society'. ${ }^{231}$ Nevertheless, the NCC is believed to have a 'general competence' in regard to 'all matters of tradition and custom and [makes] recommendations for the preservation and promotion of niVanuatu culture and languages' ${ }^{232}$ In fact, the Vanuatu Parliament may consult with the NCC in regard to any bill under consideration, ${ }^{233}$ softening any boundary between the two systems.

224 Constitution of the Republic of Vanuatu, Chapter 2, Part 1, article 5[1].

225 Ibid.

226 Ibid., Chapter 15, article 95[3].

227 Ibid., Chapter 8, article 47[1].

228 Ibid., Chapter 2, Part 2, article 7[h].

229 Ibid., Chapter 8, article 52.

230 Lindstrom, 'Chiefs in Vanuatu today', p. 212.

231 Ibid.

232 Constitution of the Republic of Vanuatu, Chapter 5, item 30[1].

233 Ibid., Chapter 5, item 30(2). 
In actual practice, the two systems often compete for jurisdiction in criminal cases, all of which should be heard in state rather than kastom courts. ${ }^{234}$ A recent gang rape allegation, made 34 years after Vanuatu achieved independence and the Constitution came into effect, helps make the point. Extramarital rape is a crime in Vanuatu, punishable by up to life imprisonment by state courts. ${ }^{235}$ A 28 -year-old woman from Tanna, an island in the southern part of the archipelago, alleged she was gang raped by six Tanna males. Although the crime was reported, the survivor and her chief each brought a letter to the prosecutor's office in May 2014 requesting that charges be dropped on the grounds that the assailants had been fined and had performed a kastom ceremony, paid a fine, and been beaten, albeit 'lightly', by men appointed by the chief to do so. The perpetrators had thus met the kastom conditions for a pardon and should not be punished twice, the survivor and her chief argued. ${ }^{236}$ The prosecutors for the cases 'insisted' that the case was 'now a state case and not to be dealt with in a customary way'. ${ }^{237}$ Jenny Ligo, a women's rights activist, vehemently protested against the plan to remove the case from the courts. 'It is totally degrading to the women of Vanuatu when you look at the records of the rape case, maltreatment to wives and young women ... that are either never properly addressed or simply ignored by male leaders in high positions of the government.'238 Tanna chiefs themselves were divided. The victim's chief wanted the case dismissed, but the main chiefly body on Tanna (the Nikoletan Council of Chiefs) upheld the principle that 'the law of the nation' ${ }^{239}$ should be applied. In fact the president of the Nikoletan Council of Chiefs averred that 'every criminal case needs to be dealt with in court not through custom' ${ }^{240}$ The jurisdiction of kastom courts is officially narrow: a matter of hearing cases involving theft, land and family disputes. Yet chiefs often do hear cases of incest and other kinds of sexual assault, ${ }^{241}$ and not always with the rights

\footnotetext{
234 See discussion in Miranda Forsyth, 2004, 'Beyond case law: Kastom and courts in Vanuatu', Victoria University of Wellington Law Review 35(2): 427-46, pp. 434-35.

235 United States Department of State, 2013, '2012 Country Reports on Human Rights Practices-Vanuatu', 19 April.

236 'Vanuatu chief wants gang rape case dropped', 2014, Radio New Zealand International, 12 May.

237 Ibid.

238 'Women should protest, not celebrate', 2014, Vanuatu Daily Post, 16 May.

239 'Chiefs in Vanuatu's Tanna overrule colleague on rape charges', 2014, Radio New Zealand International, 19 May.

240 Ibid.

241 AusAID, Violence Against Women in Melanesia and East Timor, p. 177.
} 
of the survivor in mind. Chiefs acting in kastom courts sometimes fine a raped girl 'for being in the wrong place or even make the girl marry the rapist', ${ }^{242}$ as one ni-Vanuatu women's rights activist put it.

As with Fiji's bulubulu reconciliation practices as described in Newland's contribution to this volume, the Vanuatu kastom system has been 'focused on peace and harmony in the community rather than on individual justice' ${ }^{243}$ It is not unheard of that a chiefly court will make a woman return to an abusive husband 'for the sake of community stability'. ${ }^{244}$ Moreover, women feel disadvantaged in kastom hearings ${ }^{245}$ which typically take place in village nakamalsmeetings from which women are typically excluded, and presided over by village chiefs, who are male. ${ }^{246}$

Dislodging the authority of kastom in the arena of gender violence has proved difficult. Merrin Mason worked for the Vanuatu Women's Centre (VWC) for 18 months in 1995 and 1996, providing legal advice to women who were victims of domestic violence. In that period, domestic violence perpetrators were not pursued in the state courts because, Mason suggests, judicial officers and police alike ${ }^{247}$ saw themselves as mediators, seeking a reconciliation between husband and wife and exhorting female victims to return to their husbands instead of pressing charges and sending perpetrators to jail. ${ }^{248}$ Besides, getting women to press charges has proven difficult as wives fear being embarrassed and what vengeful spouses and their kin might do to retaliate if they go to the police.

Contemporary constructions of gender underwrite gender inequality, despite the Vanuatu Constitution. Grace Molisa, a well-known niVanuatu leader who died in 2002, once observed that 'a female of the human species in Vanuatu traditional society is viewed as secondary and inferior to men. In childhood, a boy is allowed to assert himself,

\footnotetext{
242 Ibid.

243 Forsyth, A Bird that Flies with Two Wings, p. xviii; see also Fairbairn-Dunlop, Pacific Prevention of Domestic Violence Programme: Vanuatu Report, p. 21.

244 Forsyth, A Bird that Flies with Two Wings, p. 109.

245 AusAID, Violence Against Women in Melanesia and East Timor, p. 176.

246 Ibid.

247 Merrin Mason, 2000, 'Domestic violence in Vanuatu', in Reflections on Violence in Melanesia, ed. Sinclair Dinnen and Allison Ley, pp. 119-38, Annandale, NSW: Hawkins Press; Canberra: Asia Pacific Press, p. 119.

248 Ibid., p. 130.
} 
while a girl is continuously taught subservience' ${ }^{249}$ The exchange of customary valuables upon marriage, at least in some parts of the archipelago, is sufficient to place a wife under her husband's supervision and control, ${ }^{250}$ and husbands sometimes justify domestic violence on the grounds that they have given bridewealth. ${ }^{251}$ Indeed, the customary view tolerates domestic violence, which many find 'an acceptable aspect of marriage or cohabitation' ${ }^{252}$ This, according to Mason, 'is not a fringe or extreme position in Vanuatu. Public figures often make statements excusing men's violence and asserting men's right to dominance in Vanuatu society. ${ }^{\prime 253}$ In fact, 'violence against Women $\ldots$ is often justified as a part of kastom'. ${ }^{254}$ Nevertheless, females no less than males often prefer chiefly mediation to the foreign standards and procedures of the formal judicial system. ${ }^{255}$ Chiefly reconciliation practices do what many want: mend rather than further strain relationships, and restoring peace is what chiefly courts promise and plaintiffs and defendants often seek. And so, chiefly courts, not state courts, tend to handle most disputes. ${ }^{256}$ And so the 'strictures of kastom permeate all aspects of society, and customary practices and rules decreed by local chiefs, or by the national Malvatumauri Council of Chiefs, have the status of law, particularly in rural areas' ${ }^{257}$ Little wonder that it took the Vanuatu Government a long time to

249 Quoted in CEDAW Committee, 2004, 'Consideration of reports submitted by States parties under Article 18 of the Convention on the Elimination of All Forms of Discrimination against Women. Combined initial, second and third periodic reports of States parties, Vanuatu', CEDAW/C/VUT/1-3, p. 26, item 53.

250 Whether this is true everywhere, and to the same degree, are empirical questions. Based on what seems to have been fieldwork in the 1990s, Bronwen Douglas comments that gender relations in Aneityum, the southernmost island in the archipelago, are 'mostly benign'. Bronwen Douglas, 1998, 'Traditional individuals? Gendered negotiations of identity, Christianity and citizenship in Vanuatu', State, Society and Governance in Melanesia, Research School of Pacific and Asian Studies, Discussion papers 98/6, Canberra: The Australian National University. Roselyn Tor and Anthea Teka make it clear that there is no such thing as kastom blong Vanuatu (a culture that is uniform throughout Vanuatu) because of the archipelago's cultural diversity. See Roselyn Tor and Anthea Teka, 2004, Gender, Kastom \& Domestic Violence: A Research on the Historical Trend, Extent and Impact of Domestic Violence in Vanuatu, Port Vila: Department of Women's Affairs, p. 18.

251 Tor and Teka, Gender, Kastom \& Domestic Violence, p. 31.

252 Mason, 'Domestic violence in Vanuatu', p. 119.

253 Ibid.

254 AusAID, Violence Against Women in Melanesia and East Timor, p. 172.

255 Forsyth, A Bird that Flies on Two Wings, pp. 140-41.

256 Ibid., p. 97.

257 AusAID, Violence Against Women in Melanesia and East Timor, p. 172. 
ratify CEDAW. 'Successive governments' dragged their feet, male politicians citing 'ancestral values or kastom' as the source of their reservations. ${ }^{258}$

\section{Institution building}

Despite the continuing authority of kastom, both the Vanuatu Government and Vanuatu civil society have developed institutions supportive of women's rights.

In 1980, the Vanuatu Government established what would become the Department of Women's Affairs (DWA) 'to monitor the government's decisions on issues concerning women and ... advocate for women to have improved access to justice, health services and literacy'. ${ }^{259}$ In 2004, the DWA was tasked 'to "implement" CEDAW, presumably as a result of ... slow progress' ${ }^{260}$ In that capacity, the DWA is 'the lead government agency in gender equity, domestic violence and other CEDAW related issues' ${ }^{261}$ In 2009 a Child Desk Office was placed in the Ministry of Justice and Community Services to implement the CRC, which Vanuatu had ratified in $1992 .{ }^{262}$

Vanuatu civil society has arguably been more robust than the Vanuatu Government in developing institutions and programs supportive of women and children and their rights. The Vanuatu National Council of Women (VNCW), a civil society NGO, was founded just before independence in 1980 'to provide a forum for women's issues, to serve in an advisory capacity to Government on women's issues and to provide specific services for women' ${ }^{263}$ Area councils have been established throughout the archipelago, with VNCW representatives in all six provinces as well as in Port Vila and Luganville. ${ }^{264}$

258 Margaret Jolly, 'Woman ikat raet long human raet o no? Women's rights, human rights and domestic violence in Vanuatu', Feminist Review 52: 169-90, p. 180.

259 DWA, 'Focus: Department of Women's Affairs'.

260 CEDAW Committee, 'Consideration of reports submitted by States parties under Article 18 of the Convention on the Elimination of All Forms of Discrimination against Women, Combined initial, second and third periodic reports of States parties, Vanuatu', 2004, CEDAW/C/VUT/1-3, p. 32, item 62 .

261 Fairbairn-Dunlop, Pacific Prevention of Domestic Violence Programme, p. 44.

262 Ministry of Justice and Community Services, 'Child Desk Office'.

263 Tor and Teka, Gender, Kastom \& Domestic Violence, p. 57.

264 Ibid., p. 61. 
Vanuatu's most important civil society organisation dedicated to women's rights is the Vanuatu Women's Centre (VWC), established in 1992. The VWC participates in the rights-based trainings offered by the Fiji Women's Crisis Centre (FWCC), which serves in a managerial capacity vis-à-vis the VWC, ${ }^{265}$ training most VWC staff. Headquartered in Port Vila, the VWC has three branches that are supported with Australian funding. They are (in the order of their founding) the Sanma Counselling Centre on Santo Island in Sanma Province; the Tafea Counselling Centre on Tanna Island in Tafea Province; and, the last to be opened, the Torba Counselling Centre on Vanua Lava Island in Torba Province. ${ }^{266}$ The purpose of these branches is substantially the same as that of the Port Vila parent organisation: to counsel children and women who are the victims of violence, to conduct awareness campaigns and community education concerning women's and children's rights, and to educate survivors in their legal rights and how to exercise them.

\section{Committees Against Violence Against Women}

The VWC's signature creation is the community-based Committee Against Violence Against Women (CAVAW), the members of which 'receive training in legal literacy and counselling skills and are available to provide support to community women suffering domestic abuse or sexual assault'. ${ }^{267}$ CAVAWs are similar to the 'gatekeeper communities' the FWCC deploys in its Zero Tolerance Violence Free Campaign. Locally prominent men and women sit on the CAVAWs and are trained by the staff of the VWC in basic counselling skills, community education and human rights. The number of CAVAWs has mushroomed. In 2010, 35 CAVAWs were distributed throughout Vanuatu's six provinces. ${ }^{268}$ By 2013, this number had grown to fortyone. ${ }^{269}$ Although community based, CAVAWs operate with respect to the entire VWC network, referring serious cases to VWC branches and to VWC headquarters in Port Vila, as well as to the Vanuatu police,

265 Sue Finucane and Roselyn Tor, 2010, 'Mid term review of the Vanuatu Women's Centre phase 5, July 2007 - June 2012, final report', 30 April, p. 5.

266 'About', Vanuatu Women's Centre website.

267 AusAID, Violence Against women in Melanesia and East Timor, p. 179.

268 Finucane and Tor, 'Mid term review of the Vanuatu Women's Centre', p. 10.

269 'Australia increases support for Vanuatu Women's Center', 2013, Pacific Islands Report, 20 February. 
who also participate in CAVAWs. ${ }^{270}$ Through this referral system, the CAVAWs participate in district and national law and justice networks. At the same time, as members of local committees, CAVAW personnel provide 'a local contact so that victims can make an initial approach to a trusted community member' ${ }^{271}$ CAVAWs appear to be especially effective with respect to sexual assault. 'The girls and young women who have been sexually assaulted have placed enough trust in the CAVAWs to come forward and seek assistance.'272

Dovetailing with the CAVAWs, the VWC's 'Male Advocates Programme' trains men who are already in leadership positions (chiefs, police officers, religious and other community leaders) in women's rights and rights-based advocacy. The program emulates the FWCC's training of male advocates in requiring that advocates address their own violent behaviour. Many male advocates also participate in CAVAWs. ${ }^{273}$ Taken together, the Male Advocates Programme and the CAVAWs 'have greatly increased women's access to support and justice, particularly in rural areas where there are few other services' ${ }^{274}$ The males serving on CAVAWs set a standard of male conduct that other men find difficult to ignore. As one leader of a CAVAW observed in 2002, 'Men are beginning to respect their wives because there is now a body in place that will support the women and punish the men for mistreating them'. ${ }^{275}$ Testimonies to the effectiveness of the training that male advocates receive abound in the literature. Sgt Davis Saravanu, who is in charge of the Port Vila Family Protection Unit soon to be described, vouched for the quality of the training he had received in a speech he made at a 2013 celebration of International Women's Day at the UN. 'I am a [ni-Vanuatu] Male Advocate for ending violence against women and girls. ... I didn't used to be like this before I became a Male Advocate, I had a terrible attitude towards victims and did not see the importance or need to go out of my way to help them.'.276 Collaborating with Vanuatu chiefs, some of whom have become male advocates, has proved important to this initiative. One female CAVAW

270 Fairbairn-Dunlop, Pacific Prevention of Domestic Violence Programme: Vanuatu Report, p. 33.

271 Finucane and Tor, 'Mid term review of the Vanuatu Women's Centre', p. 26.

272 Ibid., p. 23.

273 AusAID, Violence Against Women in Melanesia and East Timor, p. 180.

274 Ibid.

275 Ibid., p. 179.

276 Dorosday Kenneth, Vola Mata and Davis Saravanu, n.d., 'Vanuatu', Pacific Islands Forum Secretariat, p. 3. 
leader in West Vanua Lava reached an agreement with the local chief that if a husband repeats violence after a report was brought to the attention of the chief, the chief will allow the CAVAW to help the wife file charges with the police', ${ }^{277}$ thus transferring the case from chiefly to state courts. ${ }^{278}$

Through CAVAWs and male advocates, the international human rights regime reaches deep into Vanuatu's rural areas, where 80 per cent of the Vanuatu population lives and where kastom still holds sway. A 2010 review of the VWC praised the VWC for all it had accomplished since its founding in $1992 .{ }^{279}$ It concluded that there was 'widespread support ${ }^{\prime 280}$ for the VWC's program against violence against women and observed that VWC initiatives had at times 'resulted in emergent gender equality and transformed gender relations in some areas'. ${ }^{281}$ With its archipelago-wide network and its linkages to the FWCC, the VWC constitutes a subversive tool for undermining patriarchal aspects, if not character, of Vanuatu kastom. And yet, as the opposition to the passage of the Family Protection Act of 2008 discussed in the next section makes clear, patriarchal norms persist, despite the efforts of the VWC.

\section{The Vanuatu Family Protection Act}

The most significant piece of legislation in recent years has been Vanuatu's Family Protection Act (FPA) of 2008, which criminalised domestic violence, strategically widening the jurisdiction of the state justice system. The bill was first drafted in $1997^{282}$ but, despite vigorous advocacy by the VWC and the Department of Women's Affairs, was opposed by the NCC and religious groups, 'who argued that it would erode the authority of chiefs in kastom courts and promote the breakdown of families' ${ }^{283}$ 'Based on traditional values of Vanuatu and

277 AusAID, Violence Against Women in Melanesia and East Timor, p. 179.

278 Miranda Forsyth points out that transferring cases from chiefly or informal courts to state courts may be difficult as 'the state system is often inaccessible for victims of domestic violence for a variety of reasons (geographic, financial etc.) and often the police will just send the case back to the chiefs as they see it as a family issue'. Email message to author, 28 July 2014.

279 Finucane and Tor, 'Mid term review of the Vanuatu Women's Centre', p. 5.

280 Ibid., p. 6.

281 Ibid.

282 AusAID, Violence Against Women in Melanesia and East Timor, p. 173.

283 Ibid. 
on Christian principles', ${ }^{284}$ the Act mandated that police investigate anyone the officer has good reason to believe has committed domestic violence and charge the person if the investigation substantiated the accusation. ${ }^{285}$ Offenders could face prison terms of up to five years or a fine of up to 100,000 vatu (about $\$$ US890) or both. ${ }^{286}$ If an offender gave bridewealth, this could not be used as a justification for his wife bashing. ${ }^{287}$ Also, and very much like PNG's FPA, if a defendant is found guilty of domestic violence or if a spouse is judged likely to engage in domestic violence, a Family Protection Order (FPO) can be issued against the offender to safeguard family members. ${ }^{288}$ Anyone who violates an FPO will be imprisoned for up to two years or required to pay a fine not to exceed 50,000 vatu (about \$US445) or both. ${ }^{289}$ This is again regardless of whether the person against whom the FPO is issued paid bridewealth to the victim and her family. ${ }^{290}$

Although the bill claimed to be based on Christian values and traditional principles, it was opposed, as said, by the pro-kastom NCC, which unanimously argued that it was 'a Western bill and did not suite [sic] Vanuatu Society [emphasis removed] ${ }^{291}$ Some saw it as a 'Women's Rights Movement charade designed to grant women more power to destabilise the status quo in Melanesian society' ${ }^{292}$ After parliament passed the bill, the Vanuatu Christian Council challenged the bill on the grounds that it was unconstitutional, but the Vanuatu Supreme Court determined that the bill was constitutional, ${ }^{293}$ making it the law of the land.

A striking example of insurgency against the bill is the backlash movement that John Taylor, one of the contributors to this volume, has described elsewhere: the Violence Against Men (VAM) movement of Luganville mentioned in the introduction to this volume. ${ }^{294}$ In 2005,

\footnotetext{
284 Republic of Vanuatu, 2008, Family Protection Act, item 1(2).

285 Ibid., item 44.

286 Ibid., item $10(1)$.

287 Ibid., item $10(2)$

288 Ibid., item 11(1)

289 Ibid., item 21(1).

290 Ibid., item 21(2).

291 Fairbairn-Dunlop, Pacific Prevention of Domestic Violence Programme: Vanuatu Report, p. 23.

292 The Ni Vanuatu, 26 August 2004, quoted in Fairbairn-Dunlop, Pacific Prevention of Domestic Violence Programme: Vanuatu Report, p. 23.

293 AusAID, Stop Violence, p. 93.

294 John P. Taylor, 2008, 'The social life of rights: “Gender antagonism", modernity and raet in Vanuatu', The Australian Journal of Anthropology 19(2): 165-87.
} 
during Taylor's extended fieldwork in Vanuatu, some Luganvillean men denounced human rights as a foreign, neocolonial and anti-male discourse, ${ }^{295}$ embracing kastom and Christianity for their perceived benign hierarchical and patriarchal values instead. The movement crystallised very much in the context of the Family Protection Bill and the rights-based measures taken by the Vanuatu Government to compensate for the protracted delay in its passage. The VAM movement opposed these measures, the Family Protection Bill itself, and women's rights more generally. The backlash nature of the movement is clear from its purposes, which included to 'protect married men whose wives don't respect their married lives' and to 'make sure that men are always the head of the family' ${ }^{296}$ Taylor argues that the movement was attractive to those ni-Vanuatu who believed that women's rights were "unrealistic and unsuited to both the kastom and Christian values and life-ways' of "'ordinary" "ni-Vanuatu grassroots" people'. ${ }^{297}$ Participants particularly objected to the fact that the bill brought domestic violence, which VAM members considered a private matter, within the purview of the state justice system.

Given the level of controversy the bill inspired before and after its passage, just how effective has the FPA been? While support for and knowledge of the FPA was relatively high within VWC networks, outside those networks the law has remained controversial and, like PNG's FPA, has lacked implementation. Reporting six months after the passage of the act, Peggy Fairbairn-Dunlop of Auckland University of Technology noted that even in Port Vila, the national capital and headquarters of the VWC, there was still 'considerable controversy about ... whether domestic violence should be addressed within a family focussed or a rights based framework', ${ }^{298}$ reflective of what she described as 'a fierce ambivalence as to whether domestic violence is a family or a legal issue', ${ }^{299}$ fuelled in part by the constitutional recognition of customary law. ${ }^{300}$ Abused women themselves continued to seek out reconciliation through local chiefs rather than filing a complaint with the police or state courts. Nor were the police on board. In fact, the ones who Fairbairn-Dunlop interviewed 'believed

295 Ibid., p. 167.

296 Ibid., p. 168.

297 Ibid., p. 169.

298 Fairbairn-Dunlop, Pacific Prevention of Domestic Violence Programme: Vanuatu Report, p. 15.

299 Ibid., p. 22.

300 Ibid., p. 40. 
domestic violence should be dealt with within the family, village or church and in the customary way', ${ }^{301}$ not through the state system of justice, to which women living in rural areas had little access anyway. Two years after Fairbairn-Dunlop's study, an article in the Vanuatu Daily Post noted that the FPA was not being used outside Port Vila because people did not know about it and because ni-Vanuatu preferred informal (kastom) to formal modes of conflict resolution where domestic violence was concerned. ${ }^{302}$ Practically speaking, there is no viable nationwide alternative to informal systems of justice in domestic violence cases because the Vanuatu Police Force is insufficiently equipped to deal with it, especially in rural areas.

\section{Family Protection Unit}

In late 2010, the police opened the first Family Protection Unit (FPU) in Port Vila. ${ }^{303}$ The initiative was developed in collaboration with the VWC, the Australian Federal Police and the New Zealand Police, among other law enforcement bodies. The Port Vila FPU has an officerin-charge, the aforementioned male advocate Sgt Davis Saranavu, and six police officers working under him, and it operates five days a week from 7:30 a.m. to 4:30 p.m. ${ }^{304}$ The FPU targets domestic and sexual violence, and is housed with the Vanuatu Police Force, ${ }^{305}$ allowing 'a victim or a potential victim to feel safe with the official support' of the police. ${ }^{306}$ In this way, and like PNG's FSVUs and Fiji's SOUs, Vanuatu's FPUs involve police and the state justice system, of which they are a part, in domestic violence proceedings. As of 2014, there were FPUs in four of six Vanuatu provinces. ${ }^{307}$

301 Ibid.

302 'Impacts of the Family Protection Act', 2011, Vanuatu Daily Post, 16 September.

303 Tom Schermer, 2010, 'Police open "Family Protection Unit"', Vanuatu Daily Post, 26 November.

304 Ibid.

305 United Nations General Assembly, 2014, 'Report of the working group on the Universal Periodic Review: Vanuatu', 4 April, A/HRC/26/9, item 15.

306 Schermer, 'Police open "Family Protection Unit"”.

307 UNGA, 'Report of the working group on the Universal Periodic Review: Vanuatu', A/HRC/26/9, item 15. 


\section{The VWC national survey of 2011}

In 2011, the year that Fiji undertook the survey reported in Somebody's Life, Everybody's Business! the VWC, in partnership with the Vanuatu National Statistics Office, conducted a systematic survey of gender violence in Vanuatu, targeting all six provinces. The survey utilised two questionnaires - one for the household and one for individual women - which, like the 2011 FWCC survey, were adapted from the WHO Multi-country Study on Women's Health and Domestic Violence against Women. ${ }^{308}$ The study covered several islands in each of Vanuatu's six provinces and 3,619 randomly chosen households. ${ }^{309}$

The devastating findings were reported in the Vanuatu National Survey on Women's Lives and Family Relationships. Concerning women, 'There are very high rates of all forms of violence against women across all provinces, islands, age groups, education levels, and religions'. ${ }^{310}$ 'The prevalence of intimate partner violence in Vanuatu is among the highest in the world ... For most women who experience physical or sexual violence, it occurs frequently, and it is often very severe.' ${ }^{311}$ Non-partner violence is also high. 'Almost half of the women interviewed had experienced non-partner physical or sexual violence or both since they turned 15.'312 The statistics on the sexual abuse of girls are no less startling. 'The prevalence of sexual abuse of girls under the age of 15 is also one of the very highest in the world. Almost 1 in 3 women were sexually abused before the age of 15 years'; ;13 54 per cent of these had been abused 'many times.'314 Incest was also a factor. With respect to girls under 15 who had been sexually abused, the majority of perpetrators were either male family members or boyfriends. ${ }^{315}$

As elsewhere in the western Pacific, many ni-Vanuatu women acquiesce in intimate partner violence. 'The use of violence as a form of punishment and discipline is accepted as a normal part of behaviour within many families and communities ... some women say that they

\footnotetext{
308 VWC, 2011, Vanuatu National Survey on Women's Lives and Family Relationships, p. 14. 
have not sought help because the violence was "normal".'316 Sixty per cent of all respondents agreed with one or more of the stock justifications for intimate partner violence, ${ }^{317}$ such as disobedient women should be disciplined, the wife was infertile, the wife refused intercourse, the wife was unfaithful, and bridewealth had been paid. ${ }^{318}$ Despite the fact that the FPA explicitly precludes using payment of bridewealth as a justification for domestic violence, 32 per cent of the women interviewed believed that men's payment of bridewealth justified wife bashing. ${ }^{319}$

\section{Conclusion}

The trajectory in these three histories is frustratingly non-linear. What is worked out textually, in law, lacks implementation. It is easy to be pessimistic - to conclude, for example, that nothing much has changed in the western Pacific since the Beijing 'Platform for Action' of 1995 and that significant change is unlikely, since reducing gender violence would require that men relinquish the power they have long cultivated and safeguarded. Some progress has clearly been made, however, especially in Fiji and Vanuatu, where communities are participating in national initiatives that are themselves embedded in the initiatives of the international human rights regime described in the introduction and that are designed to decrease gender violence. Although the FWCC survey, conducted in 2011 and reported in Somebody's Life, Everybody's Business!, found evidence of a 'shocking' level of violence against women and children, it also noted that, because of the women's movement, 'attitudes to this problem are changing ... there is now considerable support within the community in favour of women's rights and opposition to the use of violence'. ${ }^{320}$ Moreover, 'younger women are less likely than older women to agree with statements that negate women's rights', ${ }^{321}$ suggesting a generational rift that augurs well for the advancement of women's rights. Even in PNG, institutions and laws (however imperfectly implemented) have been put in place to

\footnotetext{
316 Ibid., p. 182.

317 Ibid., p. 80.

318 Ibid., pp. $80-82$.

319 Ibid., p. 55.

320 FWCC, Somebody's Life, Everybody's Business!, p. 146.

321 Ibid., p. 151.
} 
combat gender violence, and community-based activism now emerges as a key factor in the protection of women and girls and the pursuit of their rights.

It is often said that one of the more devastating consequences of the rapid change to which PNG, Fiji and Vanuatu have been subjected in recent decades is the loss of the authority of older, married men, who in the past had exercised power over and monitored and regulated the behaviour of boys and young men. Fiji's gatekeeper committees, Vanuatu's CAVAWs, and the male advocate programs in all three countries create spaces within which the authority of older, married males can be reasserted vis-à-vis those actors - typically male youthwhom village moral majorities denounce for their deviation from local norms. The men involved in Fiji's gatekeeper committees and Vanuatu's CAVAWs are doubly beholden: to the human rights principles they have been trained to promote but also to communal standards of decency (a point that is not often made). Such committees, along with the male advocates who sometimes serve on these committees, help constitute the interstitial element so crucial to the 'vernacularization' of human rights doctrine, according to Merry. ${ }^{322}$ In this, they are far more than a conduit of exogenous norms, importing human rights principles across cultural borders. They are active synthesisers of local and international norms. The result is not 'pure' human rights principles but a viable merger of 'local structures' and norms with 'imported ideas such as women's human rights' ${ }^{323}$ The internormative, intercultural spaces these actors occupy are spaces of global NorthernSouthern engagement, through which hybrid principles and practices are spawned.

This blending of normative systems can be seen in the collaborations between the Vanuatu chief and the female head of his village's CAVAW alluded to earlier. The two agreed 'that if a husband repeats violence after a report [of domestic violence] was brought to the attention of the chief, the chief will allow the CAVAW to help the wife file charges with the police' ${ }^{324}$ In this way, given circumstances the chief and the head of the village CAVAW have themselves stipulated, the machinery

322 Sally Engle Merry, 2006, 'Transnational human rights and local activism: Mapping the middle', in Anthropology and Human Rights in a New Key, ed. Mark Goodale, American Anthropologist 108(1): 38-51.

323 Ibid., p. 48.

324 AusAID, Violence Against Women in Melanesia and East Timor, p. 179. 
of 'reconciliation' is brought to bear upon the first offence (albeit in contravention of national law) but scuttled with the second offence, which will be referred to the state justice system, with its harsh penalties. National law is honoured in the long but not in the short run, which belongs instead to customary practices and values. In effect, Vanuatu's CAVAWs are key nodes in a complex social justice network through which international and national laws are brought into dialogue with kastom and made to mesh in ways place-based actors decide are practical and just.

Such practices do not result in a 'hypodermic'-style transfer of ideology 325 but, rather, in 'customization on the part of the receiving subject'. ${ }^{326}$ This customisation has been ongoing for decades, as Daniel Evans, Michael Goddard and Don Paterson make clear in their recent discussion of the 'hybrid' courts of Melanesia: courts that 'manage a fruitful compromise between the introduced law and customary systems, and between the individual rights-oriented justice of Western societies and the sociocentric orientation of traditional notions of dispute settlement'. ${ }^{327}$ The 'custom' honoured in such courts is an "'adapted" form of custom', ${ }^{328}$ reflecting 'the presence and importance of influential local mores' ${ }^{\prime 29}$ among western Pacific peoples but also 'intermingled with Western processes and procedures' ${ }^{330}$ If this is

325 Inda and Rosaldo, 'Tracking global flows', p. 20.

326 Ibid.

327 Daniel Evans, Michael Goddard with Don Paterson, 2010, 'The hybrid courts of Melanesia: A comparative analysis of Village Courts of Papua New Guinea, Island Courts of Vanuatu and Local Courts of Solomon Islands', Justice and Development working paper series, 13/2010, p. 2. 328 Ibid., p. 18.

329 Ibid.

330 Ibid., p. 17. Such hybridisations involve 'legal pluralism'. See Evans, Goddard and Paterson, 'The hybrid courts of Melanesia', p. 2. The larger project is then to study the contexts within which such pluralistic systems emerge and the principles and practices undergirding their functionality and/or dysfunctionality. See Jonathan Aleck, 1986, 'Law reform as development policy: Customary law and the modern legal system in Papua New Guinea', MA thesis, Department of Political Science, University of Oregon; Jonathan Aleck and Jackson Rannells (eds), 1995, Custom at the Cross-Roads: The Future of Customary Law in Papua New Guinea, Port Moresby: University of Papua New Guinea; Forsyth, A Bird that Flies with Two Wings; Sally Engle Merry, 1988, 'Legal pluralism', Law and Society Review 22(5): 869-96. 
true, then human rights doctrine does indeed have a 'social life' 331 as it enters various indigenous discursive and sociopolitical fields and engages in transcultural dialogue with its other. ${ }^{332}$

Here, then, is fertile empirical and interpretive terrain wherein social scientists may enquire into how conflicting legal and moral systems do or do not find common ground. ${ }^{333}$ Who are the key agents in this process, who are their opponents, and what are the varying perspectives of the contending parties? How are human rights doctrines 'mobilized, vernacularized, resisted, reinterpreted ... transformed', ${ }^{334}$ and by whom and for what reasons? While crucial to our understanding of the complexity, pragmatics, cultural politics and semantics of human rights work in the Pacific, such investigations would also provide a nuanced, on-the-ground understanding of the cultural and historical specificities of the dynamics of globalisation, together with the corollary of those dynamics: despite claims of universality, an inevitable proliferation of difference.

\section{Acknowledgements}

I would like to thank Jonathan Aleck, Christine Bradley, Miranda Forsyth, Margaret Jolly, Dan Jorgensen, Kathy Lepani, Martha Macintyre, Signe Poulsen, Howard Van Trease and Richard Eves for the information, writings, and/or critiques they shared with me in the course of writing this chapter.

\footnotetext{
331 Richard Ashby Wilson and Jon P. Mitchell, 2003, 'Introduction: The social life of rights', in Human Rights in Global Perspective, ed. Wilson and Mitchell, pp. 1-15, London: Routledge. See also Richard A. Wilson, 2006, 'Afterword to "Anthropology and human rights in a new key": The social life of human rights', ed. Mark Goodale, American Anthropologist 108(1): 77-83.

332 Jane Cowan, Marie-Bénédicte Dembour and Richard A. Wilson, 2001, 'Introduction', in Culture and Rights: Anthropological Perspectives, ed. Jane Cowan, Marie-Bénédicte Dembour and Richard A. Wilson, pp. 1-26. Cambridge and New York: Cambridge University Press.

333 See Aletta Biersack and Martha Macintyre, 'Introduction: Gender violence and human rights in the western Pacific', this volume.

334 Jane K. Cowan, 2006, 'Culture and rights after Culture and Rights', American Anthropologist 108(1): 9-24, p. 9.
} 


\section{References}

Aisi, Robert G. 2013. Statement BY H.E. Mr Robert G. Aisi Permanent Representative of Papua New Guinea to the United Nations at the Fifty-Seventh Session of the Commission on the Status of Women. New York, 11 March. Online: www.un.org/ womenwatch/daw/csw/csw57/generaldiscussion/memberstates/ png.pdf (accessed 11 December 2015).

Aleck, Jonathan. 1986. 'Law reform as development policy: Customary law and the modern legal system in Papua New Guinea'. MA thesis, Department of Political Science, University of Oregon.

Aleck, Jonathan and Jackson Rannells (eds). 1995. Custom at the Cross-Roads: The Future of Customary Law in Papua New Guinea. Port Moresby: University of Papua New Guinea.

Amnesty International. 2006. 'Papua New Guinea: Women human rights defenders in action'. Online: www.refworld.org/ docid/4517a2ff4.html (accessed 28 November 2015).

_ 2006. 'Papua New Guinea: Violence against women: Not inevitable, never acceptable!' Online: www.refworld.org/docid/4517a4184. html (accessed 27 November 2015).

- 2009. 'Papua New Guinea: Briefing to the UN Committee on the Elimination of Discrimination Against Women: Violence Against Women'. Online: www.amnesty.org/en/library/info/ASA34/002/ 2009/en (accessed 12 December 2015).

. 2011. 'Papua New Guinea: Violence against women, sorceryrelated killings, and forced evictions'. AI submission to the UN Universal Periodic Review. Online: www.amnesty-frauen.de/Main/ Papua-Neuguinea action $=$ download \&upname $=$ asa340052010en . pdf (accessed 27 November 2015).

- 2013. 'Good news: Family protection laws passed in PNG', 26 September. Online: www.amnesty.org.au/features/ comments/32844 (accessed 28 November 2015). 
2013. 'Papua New Guinea must end "sorcery" killings and harassment', 8 February. Online: www.amnestyusa.org/news/ press-releases/papua-new-guinea-must-end-sorcery-killings-andharassment (accessed 13 December 2015).

Appadurai, Arjun. 1996. Modernity at Large: Cultural Dimensions of Globalization. Minneapolis: University of Minnesota Press.

AusAID. 2008. Violence Against Women in Melanesia and East Timor: Building on Global and Regional Promising Approaches. Report prepared by the Office of Development Effectiveness. Online: www. pacificwomen.org/wp-content/uploads/vaw_cs_full_report1.pdf (accessed 3 February 2016).

- 2009. Stop Violence: Responding to Violence Against Women in Melanesia and East Timor. Online: dfat.gov.au/about-us/publications/ Pages/stop-violence-responding-to-violence-against-women-inmelanesia-and-east-timor.aspx (accessed 20 December 2015).

- 2015. Evaluation of the RPNGC Family and Sexual Violence Units, 31 December. Online: dfat.gov.au/about-us/publications/ Documents/png-family-sexual-violence-units-evaluation.pdf (accessed 24 April 2016).

'Australia increases support for Vanuatu Women's Center'. 2013. Pacific Islands Report, 20 February. Online: pidp.eastwestcenter.org/ pireport/2013/February/02-21-16.htm (accessed 5 December 2015).

Australian Centre for Leadership for Women. 2012. 'Nazhat Shameem', 1 June. Online: www.leadershipforwomen.com.au/empowerment/ leadership/nazhat (accessed 26 December 2015).

Australian High Commission, PNG. 2014. 'Ambassador opens Family and Sexual Violence Unit in Boroko', 8 April. Online: www.png. embassy.gov.au/pmsb/235.html (accessed 13 December 2015).

Barlow, Karen. 2013. 'Fears sorcery-killings may be spreading from PNG'. ABC Radio Australia, 5 June. Online: www.radioaustralia. net.au/international/2013-06-05/fears-sorcerykillings-may-bespreading-from-png/1141104 (accessed 27 November 2015). 
Betteridge, Ashlee and Kamalini Lokuge. 2014. 'Combatting the family and sexual violence epidemic in Papua New Guinea'. Devpolicy blog. Development Policy Centre, 30 June. Online: devpolicy. org/in-brief/combatting-the-family-and-sexual-violenceepidemic-in-png-a-submission-to-the-joint-standing-committeeinquiry-20140630/ (accessed 13 December 2015).

Blackwell, Eoin. 2013. 'PNG govt backs domestic violence laws'. The Australian, News, 2 April. Online: www.theaustralian.com.au/ news/latest-news/png-govt-backs-domestic-violence-law/storyfn3dxix6-1226611122873 (accessed 13 December 2015).

- 2013. 'PNG says sorry for violence against women'. Sydney Morning Herald, 15 May. Online: news.smh.com.au/ breaking-news-world/png-says-sorry-for-violence-againstwomen-20130515-2jmj9.html (accessed 13 December 2015).

Bomai, Simon. 2015. 'NEC endorsement of the PNG national Lukautim Pikinini Bill'. Ministry of Community Development, Religion and Youth, 24 May. Online: ministryofcomdev.blogspot. com/2015_05_01_archive.html (accessed 11 December 2015).

Bradley, Christine with Jane Kesno. 2001. Family and Sexual Violence in PNG: An Integrated Long-Term Strategy. Port Moresby: Institute of National Affairs. Online: www.popline.org/node/265152 (accessed 11 December 2014).

Chandar, Reginald. 2015. 'Fiji Government has "zero tolerance" for domestic violence: $\mathrm{PM}^{\prime}$. Pacific Island Reports, 29 April. Online: pidp.eastwestcenter.org/pireport/2015/April/04-30-07.htm (accessed 2 December 2015).

Chandler, Jo. 2014. 'Violence against women in PNG: How men are getting away with murder'. Lowy Institute for International Policy, 29 August. Online: www.lowyinstitute.org/files/violence_against_ women_in_png.pdf (accessed 26 November 2015).

Chaudary, Felix. 2015. 'Callfor commitment'. Fiji Times Online, 23 March. Online: www.fijitimes.com/story.aspx?ref=archive\&id=299126 (accessed 2 December 2015). 
'Chiefs in Vanuatu's Tanna overrule colleague on rape charges'. 2014. Radio New Zealand International, 19 May. Online: www.radionz. co.nz/international/pacific-news/244808/chiefs-in-vanuatu \% 27s-tanna-overrule-colleague-on-rape-charge (accessed 2 December 2015).

Consultative Implementation and Monitoring Council (CIMC)/Family and Sexual Violence Action Committee (FSVAC). 2008. Online: 10toeacontribution. word press.com/2013/04/05/what-is-familysexual-violence-action-committee-fsvac/ (accessed 16 November 2016).

- 2014. 'Final Stage for male advocacy training—Fiji'. Hadibaiatok vol. 1, January-June, p. 5.

- n.d. 'Rape, incest, child abuse: The PNG laws have changed!!!' Online: www.inapng.com/cimc/pdf_files/LEGAL \%20 REFORM\%20BROCHURE.pdf (site discontinued).

Coutts, Geraldine. 2012. 'Fiji women's minister defends domestic violence decree'. ABC Radio Australia, 6 December. Online: www. radioaustralia.net.au/international/radio/program/pacific-beat/ fiji-womens-minister-defends-domestic-violence-decree/1056742 (accessed 2 December 2015).

Cowan, Jane K. 2006. 'Culture and rights after Culture and Rights', American Anthropologist 108(1): 9-24.

Cowan, Jane K., Marie-Bénédicte Dembour and Richard A. Wilson (eds). 2001. Culture and Rights: Anthropological Perspectives. Cambridge and New York: Cambridge University Press.

Cowan, Jane K., Marie-Bénédicte Dembour and Richard A. Wilson. 2001. 'Introduction'. In Culture and Rights: Anthropological Perspectives, ed. Jane Cowan, Marie-Bénédicte Dembour and Richard A. Wilson, pp. 1-26. Cambridge and New York: Cambridge University Press.

Davidson, Helen. 2013. 'Papua New Guinea takes first steps to combat "epidemic" of abuse'. Guardian Australia, 26 November. Online: www.theguardian.com/society/2013/nov/26/papua-new-guineatakes-steps-against-abuse (site discontinued). 
2014. 'Australia pledges $\$ 3 \mathrm{~m}$ for Papua New Guinea Centre for victims of violence'. Guardian Australia, 7 February. Online: www.theguardian.com/world/2014/feb/07/australia-pledges-3mfor-papua-new-guinea-centre-for-victims-of-violence (accessed 13 December 2015).

Department of Justice and Attorney General. 2001. 'Village Courts Policy'. Port Moresby.

Department of Women's Affairs website. Online: dwa.gov.vu/ (accessed 9 November 2015).

Digicel PNG. 2010. 'Signing of financial MOU between INA CIMCFSVAC, UNICEF and Digicel PNG Foundation', 2 February. Online: www.digicelpng.com/en/about/news/signing-of-financial-moubetween-ina-cimc-fsvac-unicef-and-digicel-png-foundation (accessed 13 December 2015).

Dinnen, Sinclair and Allison Ley (eds). 2000. Reflections on Violence in Melanesia. Annandale, NSW: Hawkins Press; Canberra: Asia Pacific Press.

Douglas, Bronwen. 1998. 'Traditional individuals? Gendered negotiations of identity, Christianity and citizenship in Vanuatu'. State, Society and Governance in Melanesia, Research School of Pacific and Asian Studies, Discussion papers 98/6, Canberra: The Australian National University. Online: ips.cap.anu.edu. $\mathrm{au} /$ publications/traditional-individuals-gendered-negotiationsidentity-christianity-and-citizenship (accessed 27 December 2015).

Evans, Daniel, Michael Goddard with Don Paterson. 2010. 'The hybrid courts of Melanesia: A comparative analysis of Village Courts of Papua New Guinea, Island Courts of Vanuatu and Local Courts of Solomon Islands'. J\&D Justice \& Development Working Paper Series 13/2010. Online: documents.worldbank.org/curated/en/966011468286312445/ pdf/620970REVISED0000public00BOX358362B.pdf (accessed 9 June 2016).

Eves, Richard. 2010. 'Masculinity matters: Men, gender-based violence and the AIDS epidemic in Papua New Guinea'. In Civic Insecurity: Law, Order and HIV in Papua New Guinea, ed. Vicki Luker and Sinclair Dinnen, pp. 47-79. Studies in State and Society in the 
Pacific, no. 6. State, Society and Governance in Melanesia Program. Canberra: ANU E Press. Online: press.anu.edu.au/publications/ series/state-society-and-governance-melanesia/civic-insecurity (accessed 4 December 2014).

Eves, Richard and Angela Kelly-Hanku. 2014. 'Witch-hunts in Papua New Guinea's Eastern Highlands Province: A fieldwork report'. In Brief 2014/4. State, Society and Governance in Melanesia. Canberra: The Australian National University. Online: ips.cap.anu.edu.au/ publications/witch-hunts-papua-new-guineas-eastern-highlandsprovince-fieldwork-report (accessed 27 November 2015).

Fairbairn-Dunlop, Peggy. 2009. Pacific Prevention of Domestic Violence Programme: Vanuatu Report. Prepared for the New Zealand Government. Wellington: Victoria University of Wellington. Online: www.ppdvp.org.nz/wp-content/media/2010/01/PPDVP-VanuatuFinal-Report-5-Nov-20093.pdf (accessed 19 December 2015).

'Family and sexual violence'. 2014. Ruby.Connection, 24 March. Online: rubyconnection.com.au/articles/2014/march/family-andsexual-violence.aspx (accessed 13 December 2015).

Femili PNG. 2014. 'Introducing Femili PNG and the Case Management Centre'. Online: www.femilipng.org/introducingthe-png-family-and-sexual-violence-case-management-centre/ (accessed 13 December 2015).

Fernandes, Aaron. 2014. 'A war on witches'. Aljazeera, 1 May. Online: www.aljazeera.com/programmes/101 east/2014/04/warwitches-20144299354589156.html (accessed 12 December 2015).

Fiji Women's Crisis Centre (FWCC). 2013. Somebody's Life, Everybody's Business! National Research on Women's Health and Life Experiences in Fiji (2010/2011): A survey exploring the prevalence, incidence and attitudes to intimate partner violence in Fiji. Suva: FWCC. Online: fijiwomen.com/wp-content/uploads/2014/11/1.pdf (accessed 5 November 2016).

—. n.d. 'About us'. Online: fijiwomen.com/?page_id=4500/\#1 (accessed 13 December 2015).

- n.d. 'Regional training program (RTP)'. Online: fijiwomen. com/?page_id=4222 (accessed 13 December 2015). 
Fiji Women's Rights Movement. 2012. 'Herstory: Celebrating 25 Years of Balancing the Scales, 1986-2011'. Suva, Fiji: FWRM.

—. n.d. 'Fiji: Family Law Bill passed'. Online: www.wluml.org/ node/1198 (accessed 10 June 2016).

Fijian Government. 2013. 'Violence free campaigns paying dividends for communities'. Press release, 6 July. Online: www.fiji.gov.fj/ Media-Center/Press-Releases/VIOLENCE-FREE-CAMPAIGNSPAYING-DIVIDENDS-FOR-COMMU.aspx (accessed 28 November 2015).

—. 2014. 'Fiji's national gender policy approved'. 25 February. Online: www.fiji.gov.fj/Media-Center/Cabinet-Releases/FIJI\%E2\% 80\%99S-NATIONAL-GENDER-POLICY-APPROVED.aspx (accessed 28 November 2015).

- 2014. 'Nazhat Shameem to be Fiji's Permanent Representative to the UN Office in Geneva', 8 May. Online: www.fiji.gov.fj/MediaCenter/Press-Releases/NAZHAT-SHAMEEM-TO-BE-FIJI\%E2\% 80\%99S-PERMANENT-REPRESENTATI.aspx?feed=news (accessed 26 December 2015).

2015. 'EVAW taskforce to meet next week', 4 September. Online: www.fiji.gov.fj/Media-Center/Press-Releases/EVAW-TASKFORCETO-MEET-NEXT-WEEK.aspx (accessed 15 December 2015).

Finucane, Sue and Roselyn Tor. 2010. 'Mid term review of the Vanuatu Women's Centre phase 5, July 2007 - June 2012', final report, 30 April. Canberra: Department of Foreign Affairs and Trade, Australian Government. Online: aid.dfat.gov.au/countries/ pacific/vanuatu/Documents/womens-centre-mid-term-review.pdf (accessed 19 December 2015).

'Focus'. n.d. Department of Women's Affairs website. Online: dwa. gov.vu/index.php/gender-protection-cluster/gender-protectioncluster (accessed 16 November 2016).

Forsyth, Miranda. 2004. 'Beyond case law: Kastom and courts in Vanuatu'. Victoria University Wellington Law Review 35(2): 427-46. Online: www.upf.pf/IMG/pdf/09_Forsyth.pdf (accessed 9 June 2016). 
2009. A Bird that Flies with Two Wings: The Kastom and State Justice Systems in Vanuatu. Canberra: ANU Press. Online: press.anu. edu.au/publications/bird-flies-two-wings (accessed 6 June 2016).

- 2013. 'Summary of main themes emerging from the conference on Sorcery and Witchcraft-Related Killings in Melanesia, 5-7 June 2013, ANU, Canberra'. Outrigger: Blog of the Pacific Institute, The Australian National University. Online: pacificinstitute.anu.edu. au/outrigger/2013/06/18/summary-sorcery-witchcraft-relatedkillings-in-melanesia-5-7-june-2013/ (accessed 27 November 2015).

- 2014. 'New draft national action plan to address sorcery accusation-related violence in $\mathrm{PNG}^{\prime}$. In Brief 2014/18. State, Society and Governance in Melanesia. Canberra: The Australian National University. Online: ips.cap.anu.edu.au/sites/default/files/ IB-2014-18-Forsyth-ONLINE.pdf (accessed 10 June 2016).

Forsyth, Miranda and Richard Eves. 2015. 'The Problems and victims of sorcery and witchcraft practices and beliefs in Melanesia: An introduction'. In Talking it Through: Responses to Sorcery and Witchcraft Beliefs and Practices in Melanesia, pp. 1-19. Canberra: ANU Press. Online: press.anu.edu.au/publications/series/pacificseries/talking-it-through (accessed 11 April 2016).

'FWRM pays tribute to former journalist and women human rights defender'. 2015. The Jet, 9 April. Online: www.thejetnewspaper. com/2015/04/09/fwrm-pays-tribute-to-former-journalist-andwomen-human-rights-defender/ (accessed 15 December 2015).

Garap, Sarah. 1999. 'Struggles of women and girls in Simbu Province'. Development Bulletin 50: 47-50. Online: crawford.anu.edu.au/ rmap/devnet/devnet/db-50.pdf (accessed 22 December 2015).

George, Nicole. 2012. Situating Women: Gender Politics and Circumstance in Fiji. Canberra: ANU E Press. Online: press.anu. edu.au? $\mathrm{p}=154311$ (accessed 28 November 2015).

Gibbs, Philip. 2012. 'Engendered violence and witch-killing in Simbu'. In Engendering Violence in Papua New Guinea, ed. Margaret Jolly, Christine Stewart and Carolyn Brewer, pp. 107-35. Canberra: ANU E Press. Online: press.anu.edu.au/publications/engenderingviolence-papua-new-guinea (accessed 13 December 2015). 
. 2015. 'Confronting sorcery accusation violence in PNG: Will PNG's Sorcery National Action Plan be able to stop the torture and murder of those accused of witchcraft?' Asia and the Pacific Policy Society, Policy Forum, November. Online: www. policyforum.net/confronting-sorcery-accusation-violence-in-png/ (accessed 28 November 2015).

Goddard, Michael. 2009. Substantial Justice: An Anthropology of Village Courts in Papua New Guinea. Oxford: Berghahn.

GoPNG. 1975. Constitution of the Independent State of Papua New Guinea. Online: www.pngfacts.com/uploads/1/1/3/2/11320972/ papua_new_guinea_constitution.pdf(accessed 12 December 2015).

GoPNG. 2002. Criminal Code (Sexual Offences and Crimes Against Children) Act. Online: www.geneva-academy.ch/RULAC/pdf_state /PNG-Crim-Code-Sexual-Offences-Children-ccoacaca2002462.pdf (accessed 8 May 2016).

GoPNG. 2009. Lukautim Pikinini (Child) Act. Online: www.paclii.org/ pg/legis/num_act/lpa2009235.pdf (accessed 8 May 2016).

GoPNG. 2013. Family Protection Bill (PNG). Online: archive.org/ details/FamilyProtectionBillFinal19.4.13 (accessed 8 May 2016).

HELP Resources Inc. 2005. 'A situational analysis of child sexual abuse and the commercial sexual exploitation of children in Papua New Guinea'. Port Moresby: UNICEF PNG.

Highlands Women Human Rights Defenders Movement website. n.d. 'About us'. Online: womenrightsdefenders.wix.com/ papuanewguinea\#!about_us/csgz (accessed 28 November 2015)'.

- n.d. 'Themes'. Online: womenrightsdefenders.wix.com/ papuanewguinea\#!themes/c21 kz (accessed 28 November 2015).

Hilsdon, Anne-Marie, Martha Macintyre, Vera Mackie and Maila Stivens (eds). 2000. Human Rights and Gender Politics: Asia-Pacific Perspectives. London and New York: Routledge. 
Howes, Stephen, Kamalini Lokuge, Daisy Plana and Ume Wainetti. 2013. 'Responding to family and sexual violence in PNG: The case for a Case Management Centre'. DevPolicyBlog, 11 July. Online: devpolicy. org/responding-to-family-and-sexual-violence-in-png-the-case-fora-case-management-centre-20130711/ (accessed 13 December 2015).

Human Rights Watch. 2015. Bashed Up: Family Violence in Papua New Guinea, 4 November. Online: www.hrw.org/sites/default/files/ report_pdf/png 1115_4up.pdf (accessed 13 December 2015).

. 2015. 'Papua New Guinea: Universal Periodic Review Submission 2015', 21 September. Online: www.hrw.org/news/2015/09/21/papuanew-guinea-upr-submission-2015 (accessed 28 November 2015).

Hunt, Lynn. 2007. Inventing Human Rights: A History. New York and London: W.W. Norton \& Company.

'Impacts of the Family Protection Act'. 2011. Vanuatu Daily Post, 16 September.

Inda, Jonathan Xavier and Renato Rosaldo. 2008. 'Tracking global flows'. In The Anthropology of Globalization: A Reader(2nd edition), ed. Jonathan Xavier Inda and Renato Rosaldo, pp. 3-46. Malden, MA and Oxford: Wiley-Blackwell.

Jenkins, Carol (and the National Sex and Reproduction Research Team). 1994. National Study of Sexual and Reproductive Knowledge and Behaviour in Papua New Guinea. Monograph 10. Goroka: Papua New Guinea Institute of Medical Research.

Jolly, Margaret. 1996. 'Woman ikat raet long human raet o no? Women's rights, human rights and domestic violence in Vanuatu', Feminist Review 52: 169-90.

- 1997. 'Woman-nation-state in Vanuatu: Women as signs and subjects in the discourses of kastom, modernity and Christianity'. In Narratives of Nation in the South Pacific, ed. Ton Otto and Nicholas Thomas, pp. 133-62. Amsterdam: Harwood Academic Publishers. 
2012. 'Introduction — engendering violence in Papua New Guinea: Persons, power and perilous transformations'. In Engendering Violence in Papua New Guinea, ed. Margaret Jolly, Christine Stewart and Carolyn Brewer, pp. 1-45. Canberra: ANU E Press. Online: press. anu.edu.au/publications/engendering-violence-papua-new-guinea (accessed 10 December 2015).

. 2012. 'Prologue: The place of Papua New Guinea in contours of gender violence'. In Engendering Violence in Papua New Guinea, ed. Margaret Jolly, Christine Stewart and Carolyn Brewer, pp. xvii-xxvii. Canberra: ANU E Press. Online: press.anu.edu.au/ publications/engendering-violence-papua-new-guinea (accessed 17 November 2014).

Jolly, Margaret, Christine Stewart and Carolyn Brewer (eds). 2012. Engendering Violence in Papua New Guinea. Canberra: ANU E Press. Online: press.anu.edu.au/publications/engendering-violence-papuanew-guinea (accessed 26 April 2016).

Jorgensen, Dan. 2014. 'Preying on those close to home: Witchcraft violence in a PNG village'. The Australian Journal of Anthropology 25: $267-86$.

Kata, Alistar. 2015. 'Fiji: Death of Losana McGowan opens door for wider talks on domestic abuse'. Fiji Sun Online, 19 April. Online: www.pmc.aut.ac.nz/pacific-media-watch/fiji-death-losanamcgowan-opens-door-wider-talks-domestic-abuse-9222 (accessed 15 December 2015).

Kate, Talebula. 2015. 'Rethink on strategies to curb violence against women'. Fiji Times Online, 14 September. Online: fijitimes.com/ story.aspx?id=321674 (accessed 15 December 2015).

Kenneth, Dorosday, Vola Mata and Davis Saravanu. n.d. 'Vanuatu'. Pacific Islands Forum Secretariat, p. 3. Online: www.forumsec.org/ resources/uploads/embeds/file/VANUATU \% 281\%29.pdf (accessed 5 December 2015).

Kenneth, Gorethy. 2015. 'Under-age marriage ban'. Post-Courier, 13 March. 
Kotoisuva, Edwina (Fiji Women's Crisis Centre). 2007. 'Fiji Women's Crisis Centre: Organising against violence against women'. Paper presented at Pacific Women, Pacific Plan: Stepping up the Pace to 2010. Secretariat of the Pacific Community, 10th Triennial Conference of Pacific Women. Noumea, New Caledonia, 27-31 May.

Kumer, Peter. 2013. 'UN urges Papua New Guinea to take action after woman burned alive for witchcraft'. United Nations Association of Slovenia, 8 February. Online: www.unaslovenia.org/en/node/2125 (accessed 11 December 2015).

Lindstrom, Lamont. 1997. 'Chiefs in Vanuatu today'. In Chiefs Today: Traditional Pacific Leadership and the Postcolonial State, ed. Geoffrey M. White and Lamont Lindstrom, pp. 211-28. Stanford: Stanford University Press.

'Lukautim Pikinini Act soon to be enforced'. 2009. Post-Courier, 29 June.

'Lukautim Pikinini Act-passed in Parliament'. 2015. Ministry of Community Development, Religion and Youth, 8 June. Online: ministryofcomdev.blogspot.com/2015/06/lukautim-pikinini-actpassed-in.html (accessed 22 December 2015).

Luker, Vicki and Sinclair Dinnen (eds). 2010. Civic Insecurity: Law, Order and HIV in Papua New Guinea. Studies in State and Society in the Pacific, no. 6. State, Society and Governance in Melanesia Program. Canberra: ANU E Press. Online: press.anu.edu. $a u ? p=94091$ (accessed 26 April 2016).

Luluaki, John Y. 2003. 'Sexual crimes against and exploitation of children and the law in Papua New Guinea'. International Journal of Law, Policy and the Family 17(3): 275-307.

Macintyre, Martha. 2000. "'Hear us, women of Papua New Guinea!": Melanesian women and human rights'. In Human Rights and Gender Politics: Asia-Pacific Perspectives, ed. Anne-Marie Hilsdon, Martha Macintyre, Vera Mackie and Maila Stivens, pp. 147-71. London and New York: Routledge. 
Manjoo, Rahida. 2013. 'Report of the Special Rapporteur on violence against women, its causes and consequences, on her mission to Papua New Guinea (18-26 March 2012)'. United Nations General Assembly, Human Rights Council, A/HRC/23/49/Add.2. 2013. Online: reliefweb. int/report/papua-new-guinea/report-special-rapporteur-violenceagainst-women-its-causes-and-consequences (accessed 11 December 2015).

Maria. 2015. 'Papua New Guinea needs its Sorcery National Action Plan as soon as possible!' 24 October. Online: www.stopsorceryviolence. org/papua-new-guinea-needs-sorcery-national-action-plan-soonpossible/ (accessed 28 November 2015).

Mason, Merrin. 2000. 'Domestic violence in Vanuatu'. In Reflections on Violence in Melanesia, ed. Sinclair Dinnen and Allison Ley, pp. 119-38. Annandale, NSW: Hawkins Press; Canberra: Asia Pacific Press.

Médecins Sans Frontières (MSF) (Doctors Without Borders). 2013. 'Papua New Guinea: A comprehensive response to family and sexual violence is crucial', 25 November. Online: www.msf.org/en/ article/papua-new-guinea-comprehensive-response-family-andsexual-violence-critical (accessed 16 November 2016).

- 2016. 'Return to abuser: Gaps in services and a failure to protect survivors of family and sexual violence in Papua New Guinea', 1 March. Online: www.msf.org.za/msf-publications/return-to-abuserabuse-survivors-family-sexual-violence (accessed 24 April 2016).

Merry, Sally Engle. 1988. 'Legal pluralism'. Law and Society Review 22(5): 869-96.

2006. 'Transnational human rights and local activism: Mapping the middle'. In Anthropology and Human Rights in a New Key, ed. Mark Goodale. American Anthropologist 108(1): 38-51.

- 2006. Human Rights and Gender Violence: Translating International Law into Local Justice. Chicago: University of Chicago Press. 
Ministry for Social Welfare, Women and Poverty Elimination. 2014. 'Fiji's national report on the 20-year review of the implementation of the Beijing Platform for Action'. Online: www.unwomen. org/ /media/headquarters/attachments/sections/csw/59/national_ reviews/fiji_review_beijing20.ashx (accessed 28 November 2015).

Ministry for Women and Culture. 1998. 'The Women's Plan of Action 1999-2008'. Online: www.svri.org/fijinational.pdf (accessed 28 November 2015).

Ministry of Justice and Community Services. 'Child Desk Office'. Online: www.mjcs.gov.vu/index.php/justice-sector/child-desk-office (accessed 19 December 2015).

'New crime decree in Fiji to assist fight against sexual abuse'. 2010. Solomon Times Online, 25 January. Online: www.solomontimes. com/news/new-crime-decree-in-fiji-to-assist-fight-against-sexualabuse/4844 (accessed 14 December 2015).

Otto, Ton and Nicholas Thomas (eds). 1997. Narratives of Nation in the South Pacific. Amsterdam: Harwood Academic Publishers.

Pedersen, Niklas. 2015. 'Fiji women's minister calls gender violence a "national shame"". Pacific Island Reports, 10 September. Online: pidp.eastwestcenter.org/pireport/2015/September/09-11-11.htm (accessed 15 December 2015).

'PNG defines marriage age'. 2015. Radio New Zealand International, 14 March. Online: www.radionz.co.nz/international/pacific-news /268648/png-defines-marriage-age (accessed 12 December 2015).

PNG Law Reform Commission. 1992. 'Final Report on Domestic Violence. Report No. 14'. Boroko, N.C.D. Papua New Guinea.

Pollak, Sorcha. 2013. 'Woman burned alive for witchcraft in Papua New Guinea'. Time Magazine, 7 February. Online: newsfeed.time. com/2013/02/07/woman-burned-alive-for-witchcraft-in-papuanew-guinea/ (accessed 21 December 2015).

Republic of Fiji Islands. 2003. Family Law Act. Online: www.ilo. org/dyn/natlex/docs/ELECTRONIC/66125/69852/F1469246504/ FJI66125.pdf (accessed 8 May 2016). 
Republic of Fiji Islands Government Gazette. 2009. Domestic Violence Decree, 14 August. Online: www.judiciary.gov.fj/images/dvro/Domestic \%20Violence\%20Decree\% 202009.pdf (accessed 16 November 2016).

Republic of Fiji Islands Government Gazette. 2009. Crimes Decree, 5 November. Online: www.fiji.gov.fj/getattachment/604e3lfc-c7bl4la0-9686-71377917b6eb/Decree-No-44---Crimes-Decree-2009 -(pdf).aspx (accessed 16 November 2016).

Republic of Vanuatu. 1980. Constitution of the Republic of Vanuatu. Online: www.wipo.int/wipolex/en/text.jsp?file_id= 195747 (accessed 19 December 2015).

Republic of Vanuatu. 2008. Family Protection Act. Online: www.ilo. org/dyn/natlex/docs/ELECTRONIC/88503/101220/F1853954544/ VUT88503.pdf (accessed 8 May 2016).

Robinson, Nancy. 2013. 'Statement on sorcery-related killings and impunity in Papua New Guinea'. Paper presented at the Sorcery and Witchcraft-related Killings in Melanesia: Culture, Law and Human Rights Perspectives Conference. The Australian National University, Canberra, 5-7 June. Online: un.org.au/files/2013/06/ Statement-on-Sorcery-related-Killings-and-Impunity-in-PapuaNew-Guinea.pdf (accessed 27 November 2015).

Rokosuka, Elizabeth. 2014. 'Zero tolerance violence free communities to report on crimes'. Fijivillage.com, 6 July. Online: fijivillage.com/ news/Zero-Tolerance-Violence-Free-communities-to-report-oncrimes-s52r9k/ (accessed 15 December 2015).

Schermer, Tom. 2010. 'Police open "family protection unit"'. Vanuatu Daily Post, 26 November. Online: www.dailypost.vu/content/ police-open- $\%$ E2 $\% 80 \% 98$ family-protection-unit $\%$ E2\% 80\%99 (site discontinued).

Seeds Theatre Group Inc. 2015. 'Male advocacy for human rights', 25 June. Online: www.seedstheatre.org/male-advocacy-for-humanrights/ (accessed 8 June 2016). 
Setepano, Nellie. 2013. 'PNG "Haus Krai" movement gains support abroad'. Pacific Islands Report, East-West Center, Honolulu: University of Hawai'i. Online: pidp.eastwestcenter.org/ pireport/2013/May/05-14-12.htm (accessed 19 September 2014). Originally published in the PNG Post-Courier, 13 May.

- 2016. 'PNG marriage laws to be amended as part of reform bundle to legally recognize traditional marriage and protect minors'. Pacific Islands Report, 22 August. Online: www.pireport. org/articles/2016/08/22/png-marriage-laws-be-amended-partreform-bundle-legally-recognize-traditional (accessed 1 December 2016).

Shameem, Nazhat. 2012. 'The Domestic Violence Decree 2009, Fiji'. Fiji Judiciary Criminal Law Workshop for Judges and Magistrates, 14 June. Online: www.fijileaks.com/uploads/1/3 /7/5/13759434/naz_on_the_domesticviolence-decree2009.pdf (accessed 14 December 2015).

Siegel, Matt. 2013. 'Papua New Guinea acts to repeal sorcery law after strife'. New York Times, 29 May. Online: www.nytimes. com/2013/05/30/world/asia/papua-new-guinea-moves-to-repealsorcery-act.html (accessed 27 November 2015).

Stokes, Deborah. 2013. 'Speech by Australian High Commissioner Ms Deborah Stokes at the "Haus Krai" condemning violence against women, 15 May'. Australian High Commission Papua New Guinea. Online: www.png.embassy.gov.au/pmsb/69.html (accessed 12 December 2015).

Taylor, John P. 2008, 'The social life of rights: "Gender antagonism", modernity and raet in Vanuatu'. The Australian Journal of Anthropology 19(2): 165-87. Online: www.academia.edu/1816894/ The_Social_Life_of_Rights_Gender_Antagonism_Modernity_ and_Raet_in_Vanuatu (accessed 7 December 2015).

Taylor-Newton, Ruby. 2009. 'Twenty-five years on, Fiji Women's Crisis Centre stands as a beacon of hope for women'. Womensphere: Global Women's News, Views, and Issues, 4 September. Online: womensphere.wordpress.com/2009/09/04/twenty-five-years-onfiji-womens-crisis-centre-stands-as-beacon-of-hope-for-women/ (accessed 12 December 2015). 
Tor, Roselyn and Anthea Teka. 2004. Gender, Kastom \& Domestic Violence: A Research on the Historical Trend, Extent and Impact of Domestic Violence in Vanuatu. Port Vila: Department of Women's Affairs, Republic of Vanuatu.

UNICEF (United Nations Children's Fund) and the GoPNG. 2010. Lukautim Pikinini: Training Manual, Module 10: Child Protection Laws and Policies, pp. 154-63. Online: www.unicef.org/png/FBO_ Manual_Part_4.pdf (accessed 6 June 2016).

United States Department of State. 2013. '2012 Country Reports on Human Rights Practices-Vanuatu', 19 April. Online: www. refworld.org/docid/517e6db71d.html (accessed 19 December 2015).

'Vanuatu chief wants gang rape case dropped'. 2014. Radio New Zealand International, 12 May. Online: www.radionz.co.nz/ international/pacific-news/244103/vanuatu-chief-wants-gangrape-case-dropped (accessed 19 December 2015).

Vanuatu Women's Centre. 2011. Vanuatu National Survey on Women's Lives and Family Relationships. Online: dfat.gov.au/about-us/ publications/Documents/womens-centre-survey-womens-lives.pdf (accessed 8 December 2015).

. 'About: What the Vanuatu Women's Centre does'. Vanuatu Women's Centre. Online: vanuatuwomenscentre.org/about/ (accessed 5 December 2015).

Voice of ToRot. 2014. 'Madang police fight domestic sexual violence', 1 July. Online www.voiceoftorot.com/news/madang-police-fightdomestic-sexual-violence/ (accessed 13 December 2015).

White, Geoffrey M. and Lamont Lindstrom (eds). 1997. Chiefs Today: Traditional Pacific Leadership and the Postcolonial State. Stanford: Stanford University Press.

Wilson, Richard A. 2006. 'Afterword to "Anthropology and human rights in a new key": The social life of human rights', ed. Mark Goodale, American Anthropologist 108(1): 77-83. 
Wilson, Richard Ashby and Jon P. Mitchell. 2003. 'Introduction: The social life of rights'. In Human Rights in Global Perspective, ed. Richard Ashby Wilson and Jon P. Mitchell, pp. 1-15. London: Routledge.

Wilson, Richard Ashby and Jon P. Mitchell (eds). 2003. Human Rights in Global Perspective. London: Routledge.

'Women should protest, not celebrate'. 2014. Vanuatu Daily Post, 16 May.

Zimmer-Tamakoshi, Laura. 2001 [1997]. "'Wild pigs and dog men": Rape and domestic violence as "women's issues" in Papua New Guinea'. In Gender in Cross-Cultural Perspective, ed. Caroline B. Brettel and Carolyn F. Sargent, pp. 538-53. Englewood Cliffs, NJ: Prentice-Hall.

\section{United Nations Documents}

Committee on the Elimination of Discrimination against Women (CEDAW Committee). 2000. 'Initial report of States parties: Fiji Islands'. CEDAW/c/FJI/1. Online: www.un.org/womenwatch/daw/ cedaw/cedaw26/fjil.pdf (accessed 14 December 2015).

- 2004. 'Consideration of reports submitted by States parties under Article 18 of the Convention on the Elimination of All Forms of Discrimination against Women. Combined initial, second and third periodic reports of States parties, Vanuatu'. CEDAW/C/VUT/13. Online: www.capwip.org/readingroom/CEDAWCR/CEDAW $\% 20$ Country\%20Report \%20Vanuatu \%201st,2nd \%20\&\%203rd\%20 30Nov2005.pdf (accessed 3 December 2015).

- 2008. 'Consideration of reports submitted by States parties under article 18 of the Convention on the Elimination of All Forms of Discrimination against Women. Combined second, third and fourth periodic reports of States parties: Fiji'. CEDAW/C/FJI/2-4. Online: www.bayefsky.com//reports/fiji_cedaw_c_fiji_2_4_2008.pdf (accessed 14 December 2015).

- 2009. 'Consideration of reports submitted by States parties under article 18 of the Convention on the Elimination of All Forms of Discrimination against Women: Combined initial, second and third 
periodic report of States parties: Papua New Guinea'. CEDAW/C/ PNG/3, p. 28, item 2.2. Online: www.bayefsky.com//reports/papua_ cedaw_c_png_3_2008.pdf (accessed 27 November 2015).

Committee on the Rights of the Child. 2003. 'Consideration of reports submitted by State parties under article 44 of the Convention: Initial reports of State parties due in 2000: Papua New Guinea'. CRC/C/28/Add.20. Online: www.refworld.org/docid/3f8d18e74. html (accessed 10 June 2016).

Convention on the Elimination of All Forms of Discrimination against Women (CEDAW). 1979. UN Women. Online: www.un.org/ womenwatch/daw/cedaw/text/econvention.htm (accessed 11 December 2014).

UN Population Fund (UNFPA). 2008. 'An assessment of the state of violence against women in Fiji'. Suva: UNFPA Pacific Sub Regional Office. Online: www.un.org/womenwatch/ianwge/taskforces/vaw/ Fiji_VAW_Assessment_2008.pdf (accessed 14 December 2015).

UNGA. 2014. 'Report of the working group on the Universal Periodic Review: Vanuatu', 4 April, A/HRC/26/9. Online: www.ohchr.org/ EN/HRBodies/HRC/RegularSessions/Session26/Pages/ListReports. aspx (accessed 9 June 2016). 
This text is taken from Gender Violence \& Human Rights: Seeking Justice in Fiji, Papua New Guinea and Vanuatu, edited by Aletta Biersack, Margaret Jolly and Martha Macintyre, published 2016 by ANU Press, The Australian National University, Canberra, Australia. 